\title{
Role of Two-Pore Channels in Embryonic Development and Cellular Differentiation
}

\author{
Sarah E. Webb, Jeffrey J. Kelu, and Andrew L. Miller \\ Division of Life Science \& State Key Laboratory of Molecular Neuroscience, The Hong Kong University of \\ Science and Technology (HKUST), Clearwater Bay, Hong Kong, PRC \\ Correspondence: barnie@ust.hk
}

\begin{abstract}
Since the identification of nicotinic acid adenine dinucleotide phosphate (NAADP) and its putative target, the two-pore channel (TPC), the NAADP/TPC/ $\mathrm{Ca}^{2+}$ signaling pathway has been reported to play a role in a diverse range of functions in a variety of different cell types. TPCs have also been associated with a number of diseases, which arise when their activity is perturbed. In addition, TPCs have been shown to play key roles in various embryological processes and during the differentiation of a variety of cell types. Here, we review the role of NAADP/TPC/Ca ${ }^{2+}$ signaling during early embryonic development and cellular differentiation. We pay particular attention to the role of TPC2 in the development and maturation of early neuromuscular activity in zebrafish, and during the differentiation of isolated osteoclasts, endothelial cells, and keratinocytes. Our aim is to emphasize the conserved features of TPC-mediated $\mathrm{Ca}^{2+}$ signaling in a number of selected examples.
\end{abstract}

It was the mid-1990s when nicotinic acid adenine dinucleotide phosphate (NAADP) was first demonstrated to activate $\mathrm{Ca}^{2+}$ stores that were distinct from those sensitive to inositol 1,4,5-trisphosphate $\left(\mathrm{IP}_{3}\right)$ or cyclic adenosine diphosphoribose ([cADPR]; Lee and Aarhus 1995). NAADP was reported to be highly potent, working at concentrations as low as $\sim 10$ $20 \mathrm{nM}$ to stimulate the release of $\mathrm{Ca}^{2+}$ from microsomes prepared from the eggs of the sea urchin, Strongylocentrotus purpuratus. This was in comparison to concentrations of $\sim 75 \mathrm{nM}$ cADPR and $\sim 0.4 \mu \mathrm{M} \mathrm{IP}{ }_{3}$ required to elicit a similar $\mathrm{Ca}^{2+}$ response in the same cell preparation (Lee and Aarhus 1995). Furthermore, NAADP was also shown to induce rapid changes in intracellular $\mathrm{Ca}^{2+}$ in the intact eggs of another sea urchin species, Lytechinus pictus (Lee and Aarhus 1995; Aarhus et al. 1996). Following these early reports using sea urchins, NAADP was shown to mobilize $\mathrm{Ca}^{2+}$ in the oocytes of a number of other marine eggs, including those of the starfish, Asterina pectinifera, and the ascidian Phallusia mammillata (Albrieux et al. 1998; Santella et al. 2000; Lim et al. 2001; Moccia et al. 2006). In addition, NAADP was demonstrated to mobilize $\mathrm{Ca}^{2+}$ in a number of mammalian cell types, such as in mouse pancreatic acinar cells, rat astrocytes, human Jurkat T-lymphocytes, and guinea pig atrial myocytes (Cancela et al. 1999; Berg et al. 2000; Singaravelu and Deitmer 2006; Collins et al. 2011). Although the list of species and cell types reported to mobilize $\mathrm{Ca}^{2+}$ in response to NAADP is not exhaustive,

Editors: Geert Bultynck, Martin D. Bootman, Michael J. Berridge, and Grace E. Stutzmann

Additional Perspectives on Calcium Signaling available at www.cshperspectives.org

Copyright (C) 2020 Cold Spring Harbor Laboratory Press; all rights reserved; doi: 10.1101/cshperspect.a035170

Cite this article as Cold Spring Harb Perspect Biol 2020;12:a035170 
S.E. Webb et al.

the diversity of the selection that do (i.e., from evolutionary ancient echinoderms [Zamora and Rahman 2014] to the relatively more modern mammals [Lee and Beck 2015]), indicate the possible ubiquitous nature of this intracellular messenger. With the identification of more cell types that were responsive to NAADP, the race was on to identify the intracellular stores involved in generating the $\mathrm{Ca}^{2+}$ signals as well as the molecular identity of the NAADP receptor. With regard to the former, lysosome-related acidic organelles were identified as being the source of the $\mathrm{Ca}^{2+}$ that was mobilized by NAADP (Churchill et al. 2002; Kinnear et al. 2004). In addition, in reports where $\mathrm{Ca}^{2+}$ imaging data were presented, NAADP was described as stimulating a "local elevation of $\mathrm{Ca}^{2+"}$ or a "spatially restricted $\mathrm{Ca}^{2+}$ wave" in the eggs and cell types under investigation (Churchill et al. 2002; Kinnear et al. 2004; Calcraft et al. 2009). Furthermore, it was suggested that such localized $\mathrm{Ca}^{2+}$ signals from the lysosomes might stimulate or “trigger" longer-range $\mathrm{Ca}^{2+}$ signaling by $\mathrm{Ca}^{2+}$ induced $\mathrm{Ca}^{2+}$ release (CICR) via ryanodine receptors (RyRs) or $\mathrm{IP}_{3}$ receptors $\left(\mathrm{IP}_{3} \mathrm{Rs}\right)$ located in the membrane of the endo-/sarcoplasmic reticulum ([ER/SR]; Cancela et al. 1999; Kinnear et al. 2004). In addition, although there remains some controversy with regard to NAADP metabolism, target receptors/ion channels, and organelles involved (Guse and Diercks 2018), there is evidence to suggest that in certain cell types, NAADP stimulates the release of $\mathrm{Ca}^{2+}$ from the acidic organelles via two-pore channels (TPCs) (Calcraft et al. 2009; Galione et al. 2009; Brailoiu et al. 2010; Zhu et al. 2010; Ruas et al. 2015).

In animals, three members of this cationselective ion channel family have been identified, namely, TPC1, TPC2, and TPC3. TPC1 and TPC3 are localized on endosomes, whereas TPC2 is localized on lysosomes (Calcraft et al. 2009). There is some debate with regard to the identity of the endogenous agonists of these channels, and whether they conduct $\mathrm{Ca}^{2+}$ or $\mathrm{Na}^{+}$or indeed both (Guse 2009, 2012; Wang et al. 2012; Cang et al. 2013). TPC1 is generally understood to be a voltage-regulated channel; however, there are diverging views about whether it is an NAADP-activated $\mathrm{Ca}^{2+}$ channel (Ry- balchenko et al. 2012; Ogunbayo et al. 2015; Patel et al. 2017), or a phosphatidylinositol-35-bisphosphate $\left(\mathrm{PI}(3,5) \mathrm{P}_{2}\right)$-activated $\mathrm{Na}^{+}$channel (She et al. 2018). TPC2 is voltage insensitive and is reported to either conduct $\mathrm{Ca}^{2+}$ in response to NAADP, PI $(3,5) \mathrm{P}_{2}, \mathrm{Mg}^{2+}$ and protein kinases such as P38 and JNK (Zhang et al. 2013; Jha et al. 2014; Capel et al. 2015) or, like TPC1, conduct $\mathrm{Na}^{+}$in response to $\mathrm{PI}(3,5) \mathrm{P}_{2}$. Similarly, TPC3 has been identified as a voltage-activated $\mathrm{Na}^{+}$channel (Cang et al. 2014; Kintzer and Stroud 2018), but it might also conduct $\mathrm{Ca}^{2+}$ in response to NAADP (Ogunbayo et al. 2015).

The genes of all three TPCs (tpcns) are reported to be expressed in most vertebrates although tpcn 3 is not expressed in primates (specifically humans and chimps) or rodents (Calcraft et al. 2009). In addition, tpcns are found to a greater or lesser degree in many invertebrates, including echinoderms, ascidians, and some insects (Calcraft et al. 2009). Because of the diversity of species expressing tpcns, it has been suggested that they might be part of an ancient gene family, and thus play a crucial role in regulating a diverse variety of cell functions (Calcraft et al. 2009). Indeed, it has been shown that TPCs play a role in modulating the excitability and stimulus-secretion coupling in pancreatic $\beta$ cells (Arredouani et al. 2015); they are important for normal platelet function (Ambrosio et al. 2015), they regulate cell pigmentation (Ambrosio et al. 2016), are involved in $\beta$ adrenoceptor signaling in the heart (Capel et al. 2015), and play a role in the contraction of smooth muscle (Tugba Durlu-Kandilci et al. 2010).

Perhaps not surprisingly, evidence is accumulating to suggest that TPCs also play a role during embryonic development and cellular differentiation. We are especially interested in the role of TPC2-mediated $\mathrm{Ca}^{2+}$ signaling in the development and innervation of the skeletal muscle in zebrafish embryos (Kelu et al. 2015, 2017, 2018). This is because we had previously demonstrated that a series of distinct $\mathrm{Ca}^{2+}$ signals are generated in the developing slow skeletal muscle cells of intact zebrafish embryos, and that both $\mathrm{IP}_{3} \mathrm{Rs}$ and RyRs play a role in generating these signals (Cheung et al. 2011). In the same year, it 
TPCs in Development and Differentiation

was reported that TPC2 is expressed in skeletal muscle tissue in mouse embryos and neonates, and that the differentiation of $\mathrm{C} 2 \mathrm{C} 12$ myoblasts is stimulated by NAADP-induced $\mathrm{Ca}^{2+}$ release, and inhibited by the down-regulation of TPC2 (and TPC1; Aley et al. 2010a). In addition, it had previously been reported that NAADP-regulated localized $\mathrm{Ca}^{2+}$ signals from lysosomes initiates the global release of $\mathrm{Ca}^{2+}$ from RyRs in the SR, which stimulated the contraction of myocytes (Kinnear et al. 2004). These reports together with our own observations suggested that it would be important to investigate whether TPCs, and especially TPC2, might play some role in generating the $\mathrm{Ca}^{2+}$ signals we observed during the differentiation of slow skeletal muscle cells in zebrafish embryos.

In addition to skeletal muscle development, $\mathrm{NAADP} / \mathrm{TPC} / \mathrm{Ca}^{2+}$ signaling is also reported to play a role in other aspects of development, including the acrosome reaction (and hence activation) of mouse spermatozoa (Arndt et al. 2014) and fertilization in sea star oocytes (Ramos et al. 2014), as well as in the differentiation of various cell types, including osteoclasts, keratinocytes, and endothelial cells (Notomi et al. 2012; Favia et al. 2014; Park et al. 2015). Thus, here we review the current knowledge regarding NAADP/TPC/Ca ${ }^{2+}$ signaling during embryogenesis and tissue differentiation, and in doing so we hope to highlight the conserved features as well as the differences observed during the development of these various embryos and cell types.

\section{TPC-MEDIATED $\mathrm{Ca}^{2+}$ SIGNALING DURING EARLY DEVELOPMENTAL AND DIFFERENTIATION EVENTS}

As is quite often the case, new and important discoveries are made while working on a relatively simple nonmammalian species, and these are subsequently found to play a crucial role in the development and function of higher organisms: such was the case with the search for, and identification of, TPCs. This followed the pioneering work by Lee and colleagues who showed that NAADP could mobilize $\mathrm{Ca}^{2+}$ from an independent intracellular store other than the ER (i.e., from microsomes prepared from extracts derived from the sea urchins $S$. purpuratus [Lee and Aarhus 1995] and L. pictus [Lee and Aarhus 1995; Aarhus et al. 1996]). Similar results were then reported from ascidian and starfish oocytes (Albrieux et al. 1998; Santella et al. 2000), from plants (Navazio et al. 2000), and from higher eukaryotic calls (Cancela et al. 1999; Gambara et al. 2008; Aley et al. 2010a,b; Espositio et al. 2011), suggesting a highly conserved feature of this messenger molecule (Guse and Lee 2008), and presumably its endogenous receptor(s).

NAADP has been demonstrated to have distinct functions in a number of early developmental events, including during the acrosome reaction of sea urchin and mammalian sperm (Vasudevan et al. 2010; Arndt et al. 2014) and during fertilization in ascidian and starfish oocytes (Albrieux et al. 1998; Lim et al. 2001; Moccia et al. 2004). Thus, it is perhaps not surprising that TPCs have also been reported to play key roles in a variety of early developmental processes across a large number of cell types from a diverse range of organisms (e.g., from protozoans [Suárez-Cortés et al. 2017] to humans [Hockey et al. 2015; Ogunbayo et al. 2018]). These include the $\mathrm{Ca}^{2+}$ mobilization events that occur at fertilization of oocytes of the sea star Patiria miniata. Normally on fertilization in these oocytes, there is a rapid elevation of $\mathrm{Ca}^{2+}$ around the cortex (outermost region), called a "cortical flash," which lasts for just a few seconds. This is followed by a longer-duration propagating wave of $\mathrm{Ca}^{2+}$ that crosses the oocyte starting at the location where the sperm makes contact (Ramos et al. 2014). When the expression of TPC1, TPC2, and TPC3 were individually perturbed via the introduction of morpholino oligonucleotides (MOs), there was little effect on the cortical flash or the subsequent propagating wave of $\mathrm{Ca}^{2+}$. However, when they were concomitantly perturbed, these normally well-defined $\mathrm{Ca}^{2+}$ signals were altered; in some oocytes, the cortical flash occurred after the $\mathrm{Ca}^{2+}$ wave, whereas in others, $\mathrm{Ca}^{2+}$ waves were initiated from two locations. It was suggested that in these oocytes there is a cooperative activity among the three TPC isoforms (Ramos et al. 2014). 
S.E. Webb et al.

The pharmacological inhibition of TPCs with trans-ned-19 (Naylor et al. 2009) has been shown to prevent the migration of invasive cancer cells and reduce lung metastasis of mammary mouse cancer cells (Nguyen et al. 2017). Here, the disruption of TPC1 and TPC2 function was reported to inhibit trafficking of $\beta 1$ integrin, resulting in its accumulation in early endosomes. As a result, invasive cancer cells were no longer able to form leading edges that are required for migration. As TPCs are expressed in the embryos of a number of different species (Brailoiu et al. 2009; Zong et al. 2009; Ramos et al. 2014), and key early developmental events, especially those associated with gastrulation, rely on cell migration events (Keller 2005), it is possible that TPCs might regulate early embryological processes such as these as well.

TPCs have also been shown to play an essential role in the development and completion of the complex life cycle of the malaria-carrying protozoan, Plasmodium falciparum (SuárezCortés et al. 2017). Treatment with trans-ned19 prevented the progression of the asexual life cycle of this parasite by inhibiting the normal spontaneous $\mathrm{Ca}^{2+}$ oscillations that are generated, as well as blocking the transition of the parasite from the early to the late trophozoite stage, and the ability of the late trophozoite to develop to the multinucleated schizont stage (SuárezCortés et al. 2017).

\section{TPC2-MEDIATED $\mathrm{Ca}^{2+}$ SIGNALING DURING SKELETAL MUSCLE DEVELOPMENT}

The essential role of $\mathrm{Ca}^{2+}$ during mature muscle contraction has long been recognized (Ringer 1882). More recently, evidence has accumulated to suggest that intracellular $\mathrm{Ca}^{2+}$ regulation also plays a critical role in muscle differentiation and development (see reviews by Webb and Miller 2011; Tu et al. 2016). The initial research focused on the study and characterization of the role of ER/SR-resident $\mathrm{Ca}^{2+}$ channels (i.e., RyRs and $\mathrm{IP}_{3} \mathrm{Rs}$ ) during myogenesis. For example, Ferrari et al. (1996) demonstrated that cultured Xenopus myocytes exhibit spontaneous RyRmediated $\mathrm{Ca}^{2+}$ transients during early differen- tiation, and when these signals are inhibited, then myofibrillogenesis is disrupted (Ferrari et al. 1998). In addition, Powell et al. (2003) reported the presence of $\mathrm{IP}_{3} \mathrm{R}$-mediated nuclear $\mathrm{Ca}^{2+}$ transients in rodent myotubes, and demonstrated that these $\mathrm{Ca}^{2+}$ signals are involved in the regulation of gene transcription in muscle cells. Using live zebrafish embryos, Brennan et al. (2005) and Cheung et al. (2011) visualized and characterized a distinct pattern of $\mathrm{Ca}^{2+}$ signaling in the developing myotome. They suggested that these $\mathrm{Ca}^{2+}$ signals are mediated by RyRs and acetylcholine (Brennan et al. 2005) and/or by RyRs and $\mathrm{IP}_{3} \mathrm{Rs}$ (Cheung et al. 2011), and are crucial for myotomal patterning and myofibrillogenesis (Brennan et al. 2005; Cheung et al. 2011).

It was only relatively recently that lysosomal $\mathrm{Ca}^{2+}$ release was implicated in the regulation of myogenesis. The requirement of $\mathrm{TPC} 2 / \mathrm{Ca}^{2+}$ signaling during skeletal muscle differentiation was first demonstrated in vitro using the $\mathrm{C} 2 \mathrm{C} 12$ mouse myoblast cell line and primary murine myoblasts (Aley et al. 2010a). It was shown that in undifferentiated $\mathrm{C} 2 \mathrm{C} 12$ cells, $\mathrm{Ca}^{2+}$ was released upon stimulation by NAADP-AM (a cell-permeant form of NAADP, an agonist of TPCs) and ATP (an agonist of $\mathrm{IP}_{3} \mathrm{Rs}$ ), but not ryanodine (an agonist of RyRs when used at a low, stimulatory concentration; Aley et al. 2010a). This demonstrated the existence of the machinery required for NAADP signaling in the skeletal muscle precursor cells. It was also shown that the differentiation of $\mathrm{C} 2 \mathrm{C} 12$ cells was promoted by incubation with NAADP-AM, as indicated by the increase in both myogenin (a myogenic regulatory factor) and skNAC (a skeletal and heart muscle-specific transcription factor) transcripts, as well as an increase in the number of nuclei present in cells expressing the myosin heavy chain (a late terminal myogenic differentiation marker; Aley et al. 2010a). In addition, treatment with bafilomycin A1 (an inhibitor of lysosomal $\mathrm{H}^{+}$-ATPase, which depletes acidic $\mathrm{Ca}^{2+}$ stores) and trans-ned-19 both repressed myogenin and skNAC expression in $\mathrm{C} 2 \mathrm{C} 12$ cells and primary murine myoblasts (Aley et al. 2010a). These treatments also decreased the number of nuclei present in myosin 
TPCs in Development and Differentiation

heavy chain-positive cells (Aley et al. 2010a). It is important to note that treatment with xestospongin $\mathrm{C}$ (an $\mathrm{IP}_{3} \mathrm{R}$ inhibitor), or dantrolene (a RyR inhibitor), did not affect the expression of myogenin and skNAC or the number of nuclei in myosin heavy chain-positive cells (Aley et al. 2010a), implicating the specific requirement of NAADP signaling during myogenesis in vitro.

The expression profile of the transcripts of various $\mathrm{Ca}^{2+}$ channels (i.e., ip $p_{3} r 1-3, r y r 1-3$, and tpcn1-2) was also established in C2C12 cells and primary murine myoblasts (Aley et al. 2010a). It should be noted here, that somewhat similar to TPCs, there are multiple isoforms of both the $\mathrm{IP}_{3} \mathrm{R}$ and RyR. These are called $\mathrm{IP}_{3} \mathrm{R} 1$ to 3 , and (in mammals) RyR1 to 3, and they are encoded by the $i p_{3} r 1-3$ and ryrl-3 genes, respectively. These ER-based $\mathrm{Ca}^{2+}$ channels were first described in the mid-1980s (Berridge and Irvine 1984; Fleischer et al. 1985; Berridge 1987), and recent advances in our understanding of both are reviewed by Santulli et al. (2017). Using RT-PCR, $i p_{3} r 2$, and ryr3 were shown to be expressed in undifferentiated $\mathrm{C} 2 \mathrm{C} 12$ cells, whereas $i p_{3} r 1-3$, ryr1, and ryr3 were shown to be expressed in these cells only once they had undergone differentiation (Aley et al. 2010a). In addition, using northern blotting the relative level of expression of tpcn 1-2 was characterized during the differentiation of $\mathrm{C} 2 \mathrm{C} 12$ cells. The results showed that the expression of $t p c n 2$ preceded the induction of differentiation, but it decreased gradually after the initiation of differentiation. In contrast, tpcn 1 was expressed at a constant level before, during, and after the differentiation process (Aley et al. 2010a). Importantly, this same temporal pattern of expression of tpcn 1 and tpcn 2 was recapitulated in primary murine myoblasts that were obtained during embryonic and postnatal development. Thus, $t p c n 2$ was strongly down-regulated during development, whereas tpcn 1 was expressed constantly throughout all of the developmental stages examined (Aley et al. 2010a). It was suggested that TPC2 signaling might be required mainly for differentiation of the skeletal muscle cells rather than for their function once differentiation is complete (Aley et al. 2010a). To test the requirement for the various TPC isoforms in the differentiation process, the expression of $t p c n 1$ and $t p c n 2$ was knocked down by transfecting $\mathrm{C} 2 \mathrm{C} 12$ cells with siRNAs against each isoform (Aley et al. 2010a). The results showed that both differentiation and the subsequent cell-cell fusion events were repressed after TPC2-knockdown, whereas the differentiation process alone was inhibited after TPC1-knockdown (Aley et al. 2010a). Together, these data support the suggestion for the requirement of NAADP/ TPC/Ca ${ }^{2+}$ signaling in skeletal muscle differentiation, and they suggest that TPC1 and TPC2 have different roles in skeletal muscle differentiation and function, such that TPC2 (but not TPC1) has a specific role in the cell fusion events that occur during differentiation, whereas TPC1 (but not TPC2) is expressed in mature muscle where it might act as a trigger to release $\mathrm{Ca}^{2+}$ from the SR via RyR1 during contraction (Aley et al. 2010a).

More recently, the role of TPC2 in mediating myogensis in vivo was demonstrated (Kelu et al. $2015,2017)$. Earlier work characterized the endogenous pattern of $\mathrm{Ca}^{2+}$ signaling in the developing myotome in zebrafish embryos (Brennan et al. 2005; Cheung et al. 2011). Using a transgenic line of zebrafish that expresses the bioluminescent $\mathrm{Ca}^{2+}$ reporter, aequorin, specifically in skeletal muscle cells, the muscle-generated $\mathrm{Ca}^{2+}$ signals were visualized (Cheung et al. 2011). Two distinct phases of $\mathrm{Ca}^{2+}$ signaling were discovered during the development of the slow muscle cells (the first myofibers to develop; Devoto et al. 1996). These were called signaling period 1 (SP1), which occurs from $\sim 17.5$ to $\sim 19.5$ hours post-fertilization (hpf), and signaling period 2 (SP2), which occurs after $\sim 23.5 \mathrm{hpf}$ (Fig. 1Aa; Cheung et al. 2011). Further pharmacological interventions suggested that the SP1 $\mathrm{Ca}^{2+}$ signals were mainly regulated by $\mathrm{IP}_{3} \mathrm{R}$ (as they were attenuated by 2-APB: an $\mathrm{IP}_{3} \mathrm{R}$ antagonist), whereas the SP2 $\mathrm{Ca}^{2+}$ signals were mainly regulated by RyR (as they were attenuated by an inhibitory concentration of ryanodine; Cheung et al. 2011). To investigate the role of TPC2-mediated $\mathrm{Ca}^{2+}$ signaling during slow muscle cell development in zebrafish embryos, Kelu et al. (2015) utilized antisense MO technology (see reviews by Blum et al. 2015; Stainier et al. 
S.E. Webb et al.

A

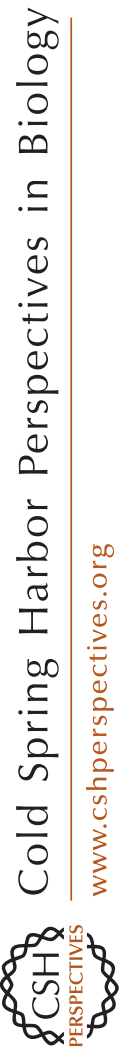

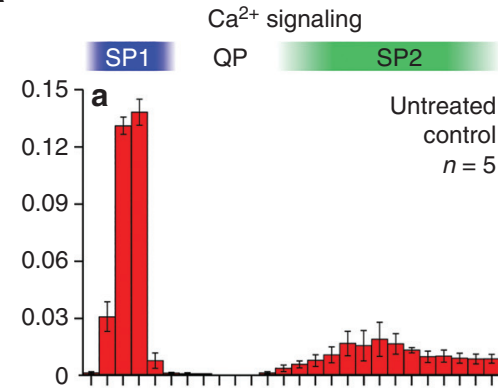
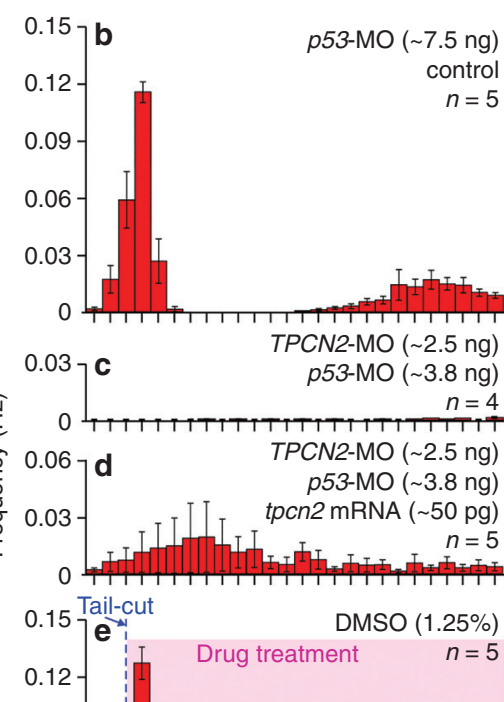

0.09

0.06

$0.03-$
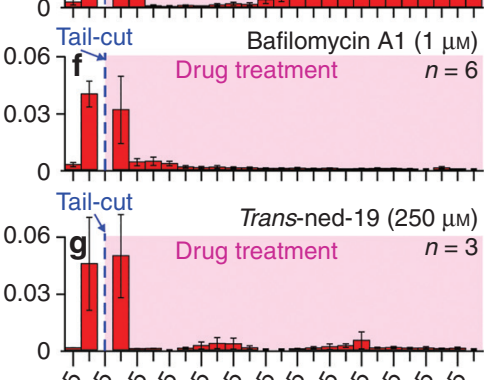

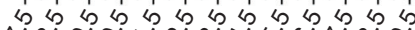

करें

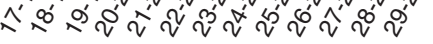

Time (hpf)

B

F-actin/myosin heavy chain $\sim 25 \mathrm{hpf}$
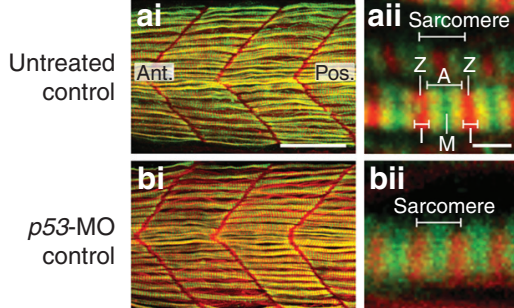

Sarcomere

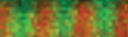

TPCN2-MO

p53-MO
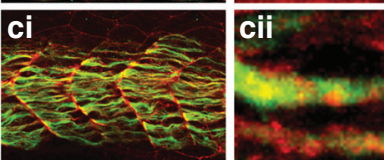

TPCN2-MO

p53-MO

tpcn2 mRNA
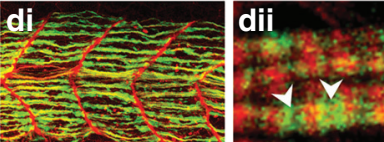

Homozygous tpcn2 dhkz1a mutant

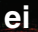

ei
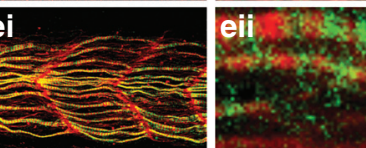

DMSO $(2.5 \%)$
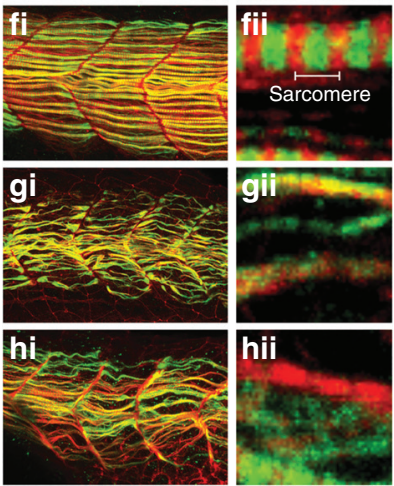

C TPC2 expression in SMCs

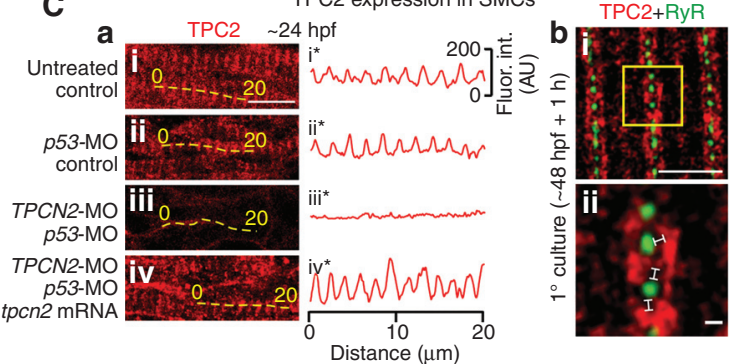

Myosin heavy

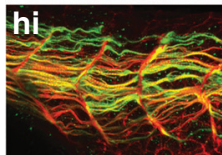

rans-ned-19

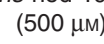

$(500 \mu \mathrm{m})$
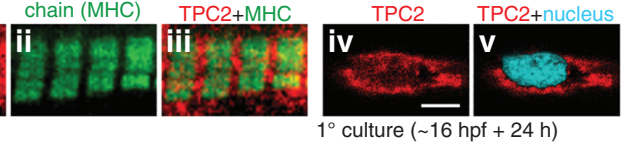

Figure 1. (Legend on following page.) 
TPCs in Development and Differentiation

2017) to knock down the expression of TPC2. Using the same aequorin transgenic line of zebrafish described by Cheung et al. (2011), Kelu et al. (2015) showed that the usual pattern of $\mathrm{Ca}^{2+}$ signaling in the developing myotome (between $\sim 17$ and $\sim 30 \mathrm{hpf}$ ) was significantly attenuated after TPCN2-MO injection (Fig. 1Ac). In addition, when a tpcn2 messenger RNA (mRNA) (that was not recognized by the TPCN2-MO) was injected into the morphants (MO-treated embryos), they demonstrated a partial rescue of the $\mathrm{Ca}^{2+}$ signaling signature (Fig. 1Ad); this supports the specificity of action of the TPCN2-MO (Kelu et al. 2015). In these experiments, a $p 53-\mathrm{MO}$ was always coinjected with the TPCN2-MO (Fig. 1Ab; Kelu et al. 2015). The coinjection of $p 53-\mathrm{MO}$ with the desired MO has been suggested to alleviate potential MO off-targeting effects that have previously been reported (Robu et al. 2007; Bedell et al. 2011). In a subsequent study, a negligible level of apoptosis was seen in the neural and somite regions (using the TUNEL assay) after the coinjection of the TPCN2-MO with p53-MO (Kelu et al. 2017); this helped to confirm the efficacy of p53 attenuation in the TPC2 morphants. As a

Figure 1. Role of TPC2 in the differentiation of the slow muscle cells in zebrafish embryos. $(A)$ Effect of morpholino oligonucleotide (MO)-based knockdown (without and with messenger RNA [mRNA] rescue) or pharmacological inhibition of TPC2 on the muscle-generated $\mathrm{Ca}^{2+}$ signals from $\sim 17$ to $\sim 30$ hours post-fertilization (hpf). These histograms show the mean \pm SEM frequency of $\mathrm{Ca}^{2+}$ signals generated every 30 min in the trunk musculature in $\alpha$-actin-aeq transgenic embryos that were $(A a)$ untreated, $(A b-A d)$ injected at the 1 - to 4 -cell stage with $(A b) p 53-\mathrm{MO},(A c)$ TPCN2-MO plus $p 53-\mathrm{MO}$, or $(A d)$ TPCN2-MO plus $p 53-\mathrm{MO}$ and tpcn2 mRNA at the amounts shown; or $(A e-A g)$ treated after the SP1 $\mathrm{Ca}^{2+}$ signals were first observed with $(A e)$ dimethylsulfoxide (DMSO), ( $A f$ ) bafilomycin A1, or ( $A g$ ) trans-ned-19 (at the concentrations shown). Calcium signaling periods 1 and 2 (SP1 and SP2), and the signaling quiet period ([QP]; Cheung et al. 2011) are shown. (B) Effect of MO-based knockdown ( \pm mRNA rescue), CRISPR/Cas9-knockout, or pharmacological inhibition of TPC2 on the organization of the trunk musculature and the formation of sarcomeres. Embryos were $(B a)$ untreated or $(B b-B d)$ injected with $(B b) p 53-\mathrm{MO},(B c)$ TPCN2-MO plus $p 53-\mathrm{MO}$, or $(B d)$ TPCN2-MO plus $p 53-\mathrm{MO}$, and tpcn2 mRNA at the amounts shown in $(A)$. In addition, $(B e)$ shows a representative homozygous tpcn 2 dhkzla mutant, and ( $B f-$ $B h)$ in some experiments embryos were treated with $(B f)$ DMSO, $(B g)$ bafilomycin A1, or $(B h)$ trans-ned-19 at the concentrations shown. All embryos were fixed at $\sim 25 \mathrm{hpf}$ and dual-labeled with phalloidin and the F59 antibody to visualize F-actin (in red) and myosin heavy chain (in green) in the trunk musculature, respectively. The panels show a series of optical sections projected as single images at (Bai-Bhi) low and (Baii-Bhii) higher magnification when the red and green channels are merged; overlapping regions are shown in yellow. The higher magnification images of the slow muscle cell myofibers reveal the presence (Baii,Bbii, Beii, Bfii) or absence (Bcii, Bgii, Bhii) of the sarcomeric banding pattern of the F-actin and myosin heavy chain. Morphants that were coinjected with $t p c n 2$ mRNA (Bdii) showed the appearance of some banding (white arrowheads) but not clear sarcomeres. Ant. and Pos. in $(\mathrm{Bai})$ are anterior and posterior, respectively. $(\mathrm{C})$ Localization of TPC2 in the slow muscle cells of (Cai) untreated embryos and in those injected with (Caii) p53-MO, (Caiii) TPCN2-MO plus p53-MO, or (Caiv) TPCN2-MO plus $p 53-\mathrm{MO}$, and tpcn2 mRNA (at the amounts shown in $(A)$ ) between the 1-4-cell stage and then fixed at $24 \mathrm{hpf}$ prior to immunolabeling. The yellow dashed lines indicate the location of line scan analyses, which were performed along individual myofibers, after which $\left(\mathrm{Cai}^{*}-\mathrm{Caiv}^{*}\right)$ line graphs were plotted to show the change in the pattern of TPC2 expression with the different treatments. $(C b)$ Visualization of TPC2 and RyR by dual-immunolabeling and dual-color stimulated emission depletion microscopy (STED) superresolution imaging. This is a representative muscle cell that was dissociated from the trunk of a zebrafish embryo at $\sim 48 \mathrm{hpf}$, plated onto a coverslip for $1 \mathrm{~h}$, and then fixed and dual-immunolabeled with the 2137A anti-TPC2 and 34C anti-RyR primary antibodies. The region bounded by the yellow square in (Cbi) is shown at higher magnification in (Cbii). The white lines in (Cbii) indicate the presence of distinct gaps between the RyR and TPC2 clusters when observed via STED imaging. ( $C c)$ Expression of TPC2 in a slow muscle cell at $\sim 24 \mathrm{hpf}$ in relation to (Cci-Cciii) that of the myosin heavy chain, and $(\mathrm{Cciv}-\mathrm{Ccv})$ the nucleus. The former images were acquired from intact embryos fixed at $\sim 24 \mathrm{hpf}$, whereas the latter images were acquired from primary cultured cells prepared from embryos at $\sim 16 \mathrm{hpf}$ and then cultured for 24 h. Scale bars, $50 \mu \mathrm{m}$ (Bai-Bhi); $2 \mu \mathrm{m}$ (Baii-Bhii); $10 \mu \mathrm{m}$ (Cai-Caiv); $2 \mu \mathrm{m}$ (Cbi); 200 $\mathrm{nm}(C b i i) ; 5 \mu \mathrm{m}(C c)$. ( $A, C a$, and $C c$ from Kelu et al. 2015; adapted, with permission, from UPV/EHU Press; $B$ and $\mathrm{Cb}$ from Kelu et al. 2017; adapted, with permission, from Elsevier.) 
complementary approach, embryos were treated with the lysosome/TPC inhibitors (i.e., bafilomycin A1 or trans-ned-19), and both were shown to result in a similar disruption to the muscle-generated $\mathrm{Ca}^{2+}$ signaling (Fig. 1Ae-Ag; Kelu et al. 2015). Together, the molecular knockdown and pharmacological inhibition approaches provided strong evidence for the involvement of lysosome/TPC2/ $\mathrm{Ca}^{2+}$ signaling during slow muscle cell development in vivo.

To further characterize the role of TPC2 during slow muscle myogenesis, two major muscle proteins, F-actin and the myosin heavy chain, were labeled after the molecular knockdown (using TPCN2-MOs), pharmacological inhibition (using bafilomycin A1 and trans-ned-19), or genetic knockout (using CRISPR/Cas9-mediated mutagenesis) of TPC2 (Fig. 1B; Kelu et al. 2017). Strikingly, a similar pattern of muscle deformity was induced using the three different approaches, such that the slow muscle fibers became more flexuous, the somites became U-shaped, and the sarcomeric banding became disrupted (Kelu et al. 2017). Importantly, the number of slow muscle cells that were formed also decreased significantly after TPC2 intervention (Kelu et al. 2017). Together, these data suggest that in zebrafish, TPC2-mediated $\mathrm{Ca}^{2+}$ release from the lysosome is essential for the formation and differentiation of slow muscle cells, the overall patterning of the skeletal myotome, and the organization of the sarcomeres with respect to their essential contractile microfilaments.

To study the expression and localization of TPC2 during slow muscle development, a zebrafish-specific TPC2 antibody was custom made and used to label endogenous TPC2 at 2-hour intervals from $\sim 16$ to $\sim 24 \mathrm{hpf}$ via whole mount immunohistochemistry (Kelu et al. 2015). These stages were chosen because of the robust development of the slow muscle cells reported to occur within this time window (Devoto et al. 1996). To examine the expression of TPC2 in the slow muscle cells, in this series of experiments the slow muscle cells were dual-immunolabeled with the TPC2 antibody and a myosin heavy chain antibody (Kelu et al. 2015). At $~ 16$ hpf, TPC2 expression in the slow muscle cells was almost undetectable; at $\sim 18 \mathrm{hpf}$, TPC2 ex- pression increased but remained relatively homogenous along the length of the slow muscle cells; at $\sim 20 \mathrm{hpf}$, TPC2 expression increased further, and started to assume a banding pattern as visualized by line-scan analysis. By $\sim 22$ and $\sim 24 \mathrm{hpf}$, a robust and clear TPC2 banding was observed in the slow myofibrils; this observation was supported by the appearance of clear peaks of TPC2 labeling in the line-scan analysis (Fig. 1Ca; Kelu et al. 2015). The specificity of the custom-made zebrafish TPC2 antibody was also validated using the TPC2 morphants, where a clear attenuation of the TPC2 labeling was seen in the slow muscle cells. In addition, the normal localization pattern was rescued to some extent when the embryos were coinjected with the TPCN2-MO and tpcn2 mRNA (Fig. 1Ca; Kelu et al. 2015). Together, these data suggested that TPC2 is expressed in the right place (i.e., in the slow muscle cells) and the right time (i.e., from $\sim 16$ to $24 \mathrm{hpf}$ ) to generate the essential $\mathrm{Ca}^{2+}$ signaling that is required for regulating the development of the slow muscle cells.

It has been suggested that $\mathrm{Ca}^{2+}$ released from the lysosome is highly localized, and as such, it might be able to trigger further $\mathrm{Ca}^{2+}$ release from the ER/SR via CICR when the acidic stores and ER/SR are in close proximity (Galione et al. 2009; Galione 2015). Using STED superresolution microscopy, Kelu et al. (2017) showed that in immunolabeled primary cultured muscle cells, TPC2 was in close proximity to the RyR and that labeling for both was localized in the sarcomeric I-band region (Fig. 1Cb) as confirmed when TPC2 was colabeled with the myosin heavy chain (Fig. 1Cc). As subsequent quantification indicated that the separation between TPC2 and the RyR was between 57 and $82 \mathrm{~nm}$ (Kelu et al. 2017), it was suggested that such a nanometer distance lies within a finite range for functional interactions between the two $\mathrm{Ca}^{2+}$ release channels to be possible (Morgan et al. 2013; Fameli et al. 2014; Penny et al. 2015). Unfortunately, as the currently available TPC2 and $\mathrm{IP}_{3} \mathrm{R}$ antibodies are both raised in the same host species (i.e., rabbit), dual-immunolabeling of the TPC2 and $\mathrm{IP}_{3} \mathrm{R}$ was not conducted. Nonetheless, the results from the dual-immunolabeling and superresolution imaging of 
TPCs in Development and Differentiation

the RyR and $\mathrm{IP}_{3} \mathrm{R}$ suggest that all three of the $\mathrm{Ca}^{2+}$ release channels are localized to the sarcomeric I-bands, and that TPC2 might be even more closely opposed to the $\mathrm{IP}_{3} \mathrm{R}$ than it is to the RyR (Kelu et al. 2017). The juxapositioning of TPC2 with the $\mathrm{IP}_{3} \mathrm{R}$ and RyR therefore supports the proposed trigger hypothesis of TPC2 function (Galione et al. 2009; Galione 2015), and indicates that the subsequent recruitment of the SR to generate globalized $\mathrm{Ca}^{2+}$ signaling via CICR might be essential for myogenesis. This hypothesis was further tested by Kelu et al. (2017), who demonstrated that in the TPC2 morphants, stimulation of the $\mathrm{IP}_{3} \mathrm{R}$ or RyR could partially rescue the development of (and the generation of $\mathrm{Ca}^{2+}$ signals in) the slow muscle cells, with stimulation of the $\mathrm{IP}_{3} \mathrm{R}$ leading to a greater extent of rescue than stimulation of the RyR (Kelu et al. 2017). This partial rescue observed might be explained if there is a pool of TPC2 that works independently of $\mathrm{IP}_{3} \mathrm{R}$ or RyR in these cells. Indeed, it has been shown that in addition to being associated with the sarcomeric I-bands, TPC2 (and LAMP1; a lysosomal marker) is also localized in the perinuclear region of slow muscle cells (Fig. 1Cc; Kelu et al. 2015). $\mathrm{IP}_{3} \mathrm{R}$ and RyR are also expressed in the perinuclear and nuclear regions of these cells but the expression pattern of all these channels (TPC2, $\mathrm{IP}_{3} \mathrm{R}$, and $\mathrm{RyR}$ ) is more diffuse than it is in the vicinity of the myofibrils, so whether they are coupled or work independently is not yet known. However, it has been reported that TPCs can function independently of the ER/ SR Ca ${ }^{2+}$ channels (Masgrau et al. 2003), and it has been suggested that the elementary $\mathrm{Ca}^{2+}$ signals generated by these channels might directly gate $\mathrm{Ca}^{2+}$-activated cation channels on the plasma membrane (Calcraft et al. 2009). This concept of distinct pools of TPC2 in cells (where one pool is coupled to the ER, while the other functions independently), has also been indicated in rat cortical neurons as the simultaneous inhibition of $\mathrm{IP}_{3} \mathrm{R}$ and RyR reduced, but did not completely block, the generation of NAADP-mediated $\mathrm{Ca}^{2+}$ signals (Brailoiu et al. 2005).

In zebrafish, it was previously proposed that the SP1 $\mathrm{Ca}^{2+}$ signals are required for slow mus- cle cell differentiation by mediating excitationtranscription (ET) coupling, whereas the SP2 $\mathrm{Ca}^{2+}$ signals are required for slow muscle cell function by mediating excitation-contraction (EC) coupling (Cheung et al. 2011). As TPC2 and LAMP1 have a perinuclear localization in primary cultured muscle cells (Fig. 1Cc), it was suggested that the activation of TPC2 around the nucleus during SP1 might stimulate $\mathrm{IP}_{3} \mathrm{Rs}$ and RyRs (which are also localized in the perinuclear/nuclear regions; Kelu et al. 2015) to modulate $\mathrm{Ca}^{2+}$-dependent transcription of muscle genes during ET coupling (Avila et al. 2001; Powell et al. 2001; Jaimovich and Carrasco 2002; Carrasco et al. 2003; Cárdenas et al. 2005; Stiber et al. 2005; Valdés et al. 2007). Indeed, the visualization of $\mathrm{Ca}^{2+}$ signals in the nucleus in zebrafish slow muscle cells was previously reported during the SP1 period (Cheung et al. 2011), where the duration of the elevated nuclear signal $(>7.5 \mathrm{sec})$ far exceeded that of the cytoplasmic signal $(\sim 0.58 \mathrm{sec})$, thus placing it in the time window for stimulating gene expression suggested by Berridge et al. (2003).

Even though the NAADP/TPC2 pathway has been implicated in agonist-evoked contractions and/ or EC coupling in both smooth muscle (Tugba Durlu-Kandilci et al. 2010; Aley et al. 2013) and cardiac muscle (Collins et al. 2011; Capel et al. 2015), relatively little is known about the its role in mediating skeletal muscle cell contraction. It was shown that the spontaneous coiling behavior of zebrafish embryos (Saint-Amant and Drapeau 1998) after TPC2-knockdown was severely retarded from $\sim 17$ to $\sim 28 \mathrm{hpf}$, but motility was partially rescued following injection of tpcn 2 mRNA (Kelu et al. 2017). In addition, when determining the touch-evoked response of embryos (Saint-Amant and Drapeau 1998), only $\sim 3 \%$ of TPC2 morphants responded to touch, when compared with $100 \%$ of the untreated control embryos. Again, a partial rescue was induced by the tpcn 2 mRNA such that $\sim 30 \%$ of the embryos responded to touch (Kelu et al. 2017). Nonetheless, further investigation is required to confirm whether the effects on the muscle function are secondary to the effects on the muscle development and motor/ sensory neuron activity after TPC2 knockdown. 
S.E. Webb et al.

In addition to the in vitro (Aley et al. 2010a) and in vivo (Kelu et al. 2015, 2017) evidence that is accumulating to indicate the essential requirement of NAADP/TPC2/Ca ${ }^{2+}$ signaling in skeletal muscle development and function, the role of lysosomal $\mathrm{Ca}^{2+}$ release during muscle autophagy and aging, as well as during myopathy and muscle repair have recently been described (Cheng et al. 2014, 2015; Lin et al. 2015). Thus, more in-depth investigations into the role of the TPC2 $/ \mathrm{Ca}^{2+}$ signaling pathway in muscle development and function might help to resolve the pathophysiology of skeletal muscle disorders.

\section{TPC2-MEDIATED $\mathrm{Ca}^{2+}$ SIGNALING DURING NEURONAL DIFFERENTIATION}

$\mathrm{Ca}^{2+}$ has long been known to regulate various aspects of neuronal development and function (reviewed by Simons 1988; Berridge 1998; Gruol et al. 2012; Kawamoto et al. 2012; Brini et al. 2014). $\mathrm{Ca}^{2+}$ entering the cell either via voltagegated channels or via receptor-operated channels, which are regulated by ionotropic neurotransmitters, acts as a second messenger of various signal transduction pathways that regulate a diverse range of cellular processes, including neuronal excitability (Berridge 1998; Roussel et al. 2006; Lu et al. 2010), neuronal gene expression (Ghosh et al. 1994; West et al. 2001), neurotransmitter release (Harvey and MacIntosh 1940; Dodge and Rahamimoff 1967; Augustine et al. 1987; Südhof 2012), and synaptic plasticity (Lamont and Weber 2012), as well as many other events that contribute to the processing and storage of information that underlie learning and memory (Gibbs et al. 1979; Baker et al. 2013). $\mathrm{Ca}^{2+}$ signaling is also involved in various aspects of the development of the nervous system (Rosenberg and Spitzer 2011), playing a role in neuronal migration (Komuro and Rakic 1992; Tam et al. 2000), growth cone motility and guidance (Henley and Poo 2004; Bolsover 2005; Gasperini et al. 2017), neurite outgrowth and branching (Lankford and Letourneau 1989; Rønn et al. 2002), and synaptogenesis (Basarsky et al. 1994; Feng et al. 2002). $\mathrm{Ca}^{2+}$ influx from the extracellular milieu via voltage-gated $\mathrm{Ca}^{2+}$ channels, and/or the mobilization of $\mathrm{Ca}^{2+}$ from the ER via activation of $\mathrm{IP}_{3} \mathrm{Rs}$ or RyRs have long been implicated in the $\mathrm{Ca}^{2+}$-regulated aspects of neuronal development and function (Bandtlow et al. 1993; Takei et al. 1998; Tam et al. 2000; Numakawa et al. 2003; Hertle and Yeckel 2007; Gasperini et al. 2017). It is not surprising, therefore, that NAADP-mediated release of cytosolic $\mathrm{Ca}^{2+}$ from acidic stores has also been demonstrated to play a role in the extension of neurites in neurons isolated from newborn rat cerebral cortex (Brailoiu et al. 2005), and induce neuronal differentiation of PC12 cells (Brailoiu et al. 2006). More recently, Zhang et al. (2013) demonstrated that TPC2 has opposing effects on different stages of neural differentiation of mouse embryonic stem cells (ESCs), such that it inhibits the early differentiation of ESCs to neural progenitors, but it is required for the later stages of neuronal differentiation.

Most recently, NAADP/TPC2-mediated $\mathrm{Ca}^{2+}$ signaling was demonstrated to play a role in the establishment of synchronized activity in the primary motor neurons (PMNs) of intact, normally developing zebrafish embryos (Kelu et al. 2018). The SAIGFF213A:GCaMP7a double transgenic line of fish was used in which the fluorescent $\mathrm{Ca}^{2+}$ indicator, GCaMP7a is expressed in the caudal PMNs (CaPs) (Muto and Kawakami 2011; Muto et al. 2011). In normally developing fish at $18 \mathrm{hpf}$, low frequency and long duration $\mathrm{Ca}^{2+}$ signals are generated, which appear to arise in an almost stochastic manner (Kelu et al. 2018). By 24 hpf, however, the CaP-generated $\mathrm{Ca}^{2+}$ signals are ipsilaterally (i.e., along the same side of the trunk) correlated and contralaterally (i.e., on opposite sides of the trunk) anticorrelated (Muto and Kawakami 2011; Muto et al. 2011; Kelu et al. 2018); thus, $\mathrm{Ca}^{2+}$ signals are normally generated synchronously first along one side of the trunk and then along the other side (Fig. 2Aa, Ad). However, Kelu et al. (2018) showed that the MOmediated knockdown (Fig. 2Ab), genetic knockout (via CRISPR/Cas9; Fig. 2Ae), or pharmacological inhibition (with bafilomycin A1 or transned-19; Fig. 2Af-Ah) of TPC2 resulted in a loss of this synchronized (i.e., both the correlation and anticorrelation) $\mathrm{Ca}^{2+}$ signaling in the CaPs. TPC2 knockdown, knockout, or inhibi- 
TPCs in Development and Differentiation
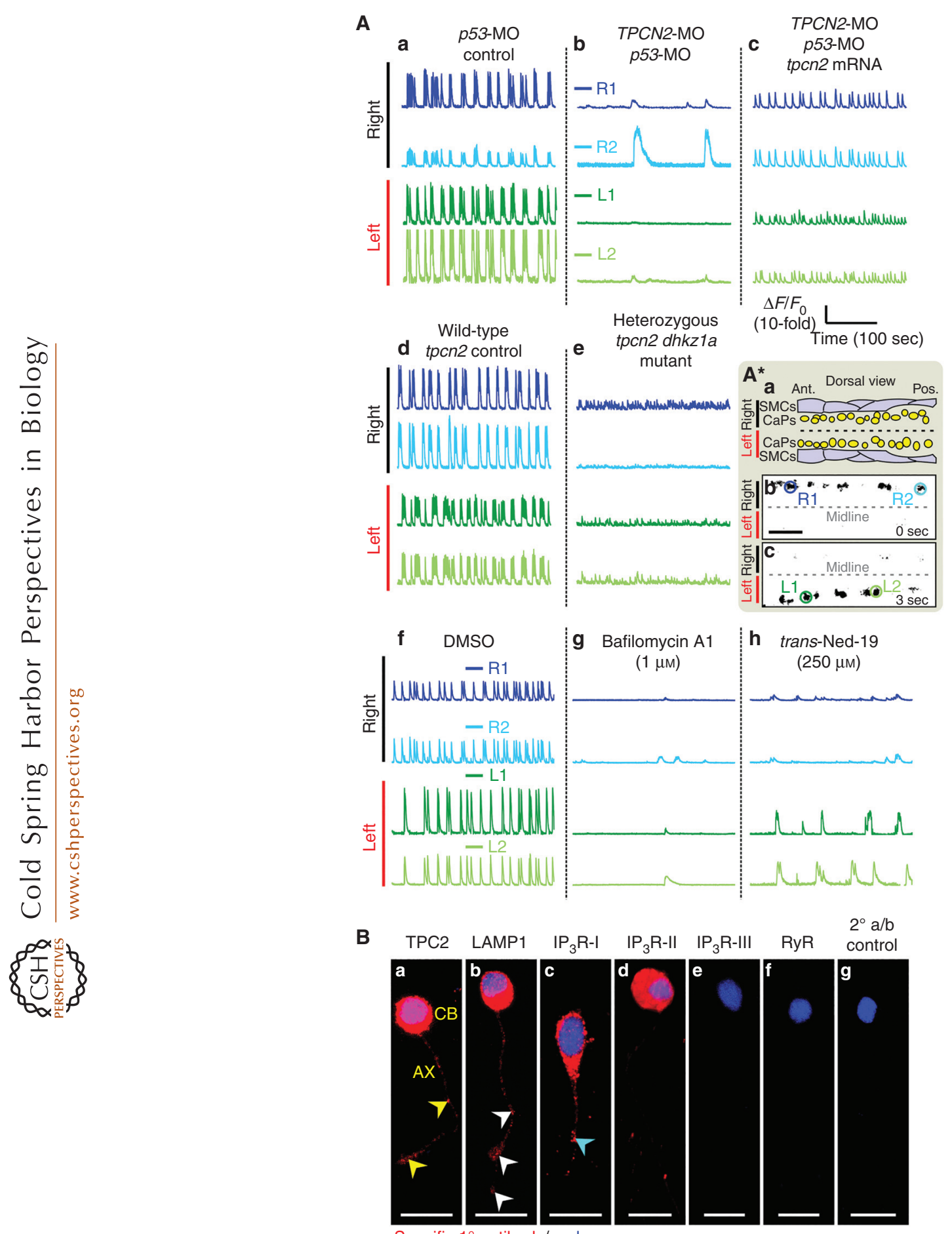

Specific $1^{\circ}$ antibody/nucleus

Figure 2. (Legend on following page.) 
S.E. Webb et al.

tion also resulted in a decrease in the frequency and amplitude of the CaP-generated $\mathrm{Ca}^{2+}$ signals and an increase in their duration. However, coinjection of embryos with TPCN2-MO and tpcn 2 mRNA resulted in the ipsilateral and contralateral pattern of $\mathrm{Ca}^{2+}$ signaling as well as the frequency, amplitude, and duration of the signals being (at least partially) rescued (Fig. 2Ac; Kelu et al. 2018). TPC2 and LAMP1 (lysosomalassociated membrane protein 1) were shown to be expressed by the CaPs both in the cell body and in clusters along the axon (Fig. 2Ba, Bb). In addition, $\mathrm{IP}_{3}$ Rs type I and II (but not $\mathrm{IP}_{3} \mathrm{R}$ type III or any of the RyR subtypes) were shown to be localized in the CaPs (Fig. 2Bc-Bf). Following MO-mediated TPC2 knockdown, treatment of embryos with the $\mathrm{IP}_{3} \mathrm{R}$ agonist, $\mathrm{IP}_{3} / \mathrm{BM}$ (but not the RyR agonists, caffeine, or ryanodine at a low agonistic concentration), partially rescued the CaP-mediated $\mathrm{Ca}^{2+}$ signals (Kelu et al. 2018). It was therefore suggested that these data support the trigger hypothesis, where the localized release of $\mathrm{Ca}^{2+}$ via TPCs in acidic stores stimulates larger-scale $\mathrm{Ca}^{2+}$ release via $\mathrm{Ca}^{2+}$ channels in the ER ( $\mathrm{IP}_{3} \mathrm{R}$ or RyR) via CICR (Fig. 3; Kin- near et al. 2004; Galione et al. 2009). Indeed, the acidic organelles and ER have previously been shown to be closely apposed in primary rat medullary neurons (Brailoiu et al. 2009), and NAADP-induced $\mathrm{Ca}^{2+}$ release has been demonstrated to be linked to the activation of the $\mathrm{IP}_{3} \mathrm{R}$ in astrocytes isolated from newborn mice (Heidemann et al. 2005), as well as to the activation of $\mathrm{IP}_{3} \mathrm{R}$ or RyR in isolated nuclei from the ganglia of adult Aplysia californica and Arbacia punctata (Bezin et al. 2008). The work by Kelu et al. (2018) provides the first evidence in an intact animal model that TPC2 is a key molecular component of the $\mathrm{Ca}^{2+}$ signaling pathway that coordinates the establishment of the motor neuronal circuitry during development.

\section{TPC2-MEDIATED $\mathrm{Ca}^{2+}$ SIGNALING DURING OSTEOCLASTOGENESIS}

Osteoclasts are giant multinucleated cells of the monocyte/macrophage family, which degrade and resorb bone (Udagawa et al. 1990). Working together with osteoblasts (which are responsible for synthesizing bone), osteoclasts regulate the

Figure 2. Role of two-pore channel 2 (TPC2) in the differentiation of the primary motor neurons in zebrafish embryos. (A) Effect of morpholino oligonucleotide (MO)-based knockdown (without and with messenger RNA [mRNA] rescue), CRISPR/Cas9 heterozygous knockout, or pharmacological inhibition of TPC2 on the spontaneous $\mathrm{Ca}^{2+}$ activity of the caudal primary motor neurons (CaPs) in SAIGFF213A;UAS:GCaMP7a embryos at $\sim 24$ hours post-fertilization (hpf). SAIGFF213A;UAS:GCaMP7a embryos were injected with (Aa) p53-MO; $(A b)$ TPCN2-MO plus $p 53-\mathrm{MO}$; or (Ac) TPCN2-MO plus $p 53-\mathrm{MO}$ and the tpcn2 mRNA at the amounts shown in Figure 1A. In addition $(A d)$, untreated SAIGFF213A;UAS:GCaMP7a embryos (termed wild-type tpcn2 controls) were imaged and the adults were crossed with homozygous tpcn2 dhkzla mutants to generate (Ae) double-transgenic heterozygous tpcn2 dhkz1a mutants. Furthermore $(A f-A h)$, some embryos were treated at $\sim 17$ hpf with $(A f)$ DMSO; $(A g)$ bafilomycin A1; or $(A h)$ trans-ned-19 (at the concentrations shown). $\left(A^{*} a\right)$ All embryos were imaged in a dorsal orientation and $\left(A^{*} b, A^{*} c\right)$ time-lapse fluorescence images were acquired to show the changes in GCaMP7a fluorescence in the CaPs at different time intervals in the various treatment groups. Regions of interest (ROIs) were placed on two selected CaP cell bodies on the left (L1 and L2) and right (R1 and R2) sides of the spinal cord. Ant. and Pos. are anterior and posterior, respectively. Scale bar, $50 \mu \mathrm{m}$. ( $A a-$ $A h$ ) Line graphs showing the $\Delta F / F_{0}$ against time (over a period of $\sim 300 \mathrm{sec}$ ) in the ROIs selected for each embryo. (B) Expression and localization of TPC2, lysosomal-associated membrane protein 1 (LAMP1), IP ${ }_{3}$ Rs, and RyRs in presumptive CaPs isolated from SAIGFF213A;UAS:GFP embryos and cultured for $24 \mathrm{~h}$. The trunk of these embryos, which express green fluorescent protein (GFP) in the CaPs, was dissected at $\sim 18 \mathrm{hpf}$. The cells were dissociated and cultured for $24 \mathrm{~h}$ and then they were immunolabeled with antibodies for $(B a)$ TPC2, $(B b)$ LAMP1, $(B c-B e)$ IP $_{3} \mathrm{R}$ types I-III, respectively, or ( $\left.B f\right)$ RyR (all subtypes). (Bg) Secondary antibody control. The cells were costained with $4^{\prime}$,6-diamidino-2-phenylindole (DAPI) to label the nuclei. Each panel is a series of optical sections that have been projected as a single confocal image, and they show the red (individual antibody) and blue (nuclei) channels when merged. CB and AX are the cell body and axon, respectively. The yellow, white, and blue arrowheads indicate TPC2, LAMP1, and $\mathrm{IP}_{3} \mathrm{R}$ type I clusters, respectively, localized along the axons. Scale bars, $10 \mu \mathrm{m}$. (From Kelu et al. 2018; adapted, with permission, from Elsevier.) 


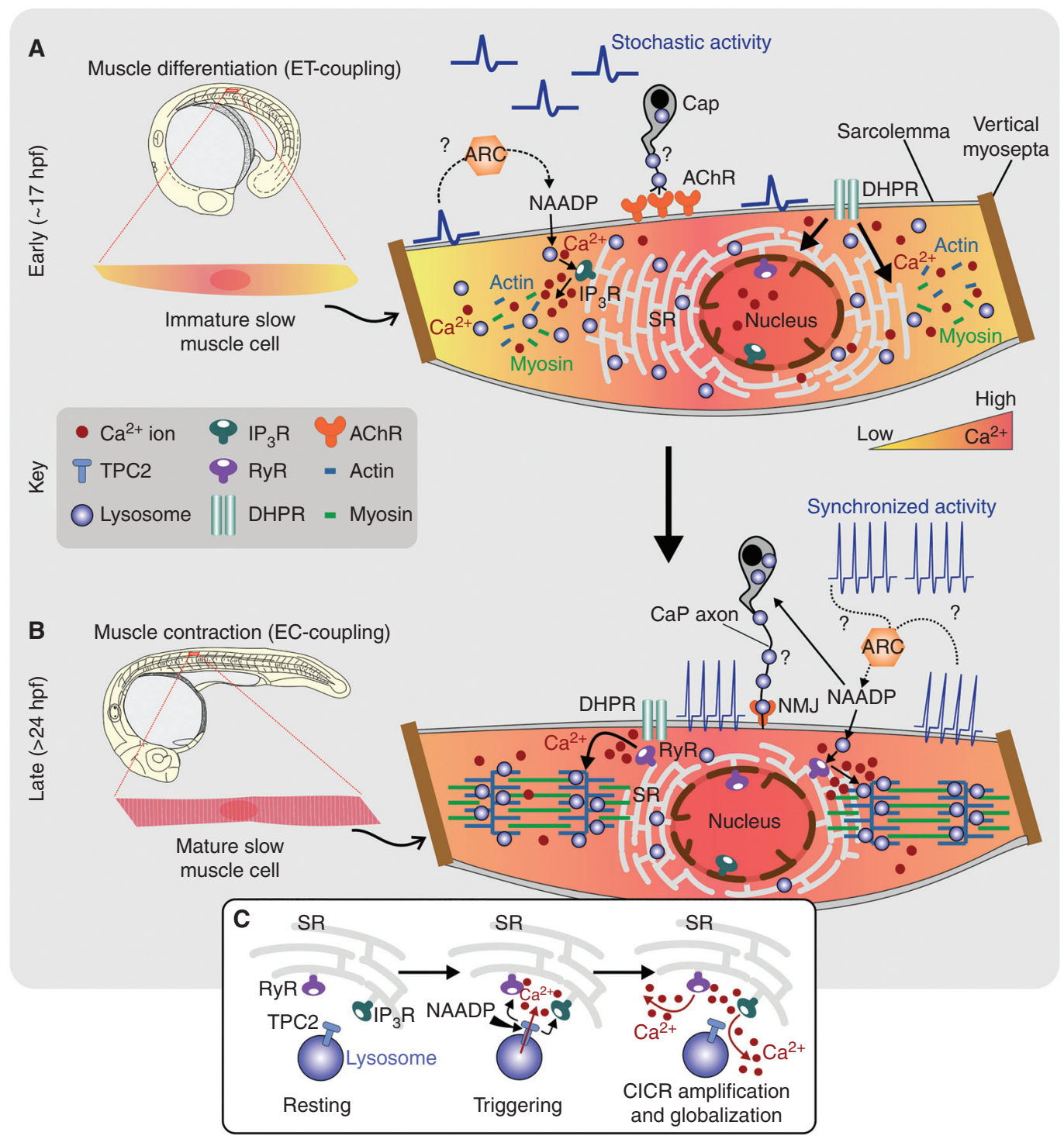

Figure 3. Proposed model of two-pore channel $2(\mathrm{TPC} 2) / \mathrm{Ca}^{2+}$ signaling during early $(\sim 17$ hours post-fertilization $[\mathrm{hpf}])$ and later $(\sim 24 \mathrm{hpf})$ slow muscle cell and primary motor neuron differentiation in zebrafish embryos. This summarizes the accumulating evidence, which suggests an essential role for $\mathrm{TPC} 2 / \mathrm{Ca}^{2+}$ signaling in the events involved in $(A)$ excitation-transcription (ET) coupling during muscle differentiation and $(B)$ excitationcontraction (EC) coupling during muscle contraction. TPC2/Ca ${ }^{2+}$ signaling appears to play a role in various aspects of neuromuscular development, including development of the spinal circuitry, outgrowth of the motor axons, formation of neuromuscular junctions, differentiation of slow muscle cells, myotomal patterning, and sarcomere formation, as well as the initiation of early motor behavior. $(C)$ Evidence also indicates that the robustness of TPC2/ $\mathrm{Ca}^{2+}$ signaling is maintained by the coordinated activation of the endo/sarcoplasmic reticulum (ER/SR) $\mathrm{Ca}^{2+}$ stores and subsequent amplification of the $\mathrm{Ca}^{2+}$ signals via $\mathrm{Ca}^{2+}$-induced $\mathrm{Ca}^{2+}$ release (CICR) within the lysosome-ER/SR junctions. ( $C$ is from Figure $2 b$ in Galione et al. 2009; adapted, with permission.) TPC2, two-pore channel 2; $\mathrm{IP}_{3} \mathrm{R}$, inositol 1,4,5-trisphosphate receptor; RyR, ryanodine receptor; DHPR, dihydropyridine receptor; AChR, acetylcholine receptor; ARC, ADP ribosyl cyclase; NMJ, neuromuscular junction. 
S.E. Webb et al.

overall mass and structure of the skeleton. The major players and main mechanisms that control osteoclast differentiation and bone resorption have been described previously and are the subject of a number of excellent reviews (Chambers 2000; Teitelbaum 2000; Boyle et al. 2003; Asagiri and Takayanagi 2007; Teitelbaum 2007; Yavropoulou and Yovos 2008; Nakashima et al. 2012). In brief, it is known that osteoclasts differentiate under the control of two main cytokines, receptor activator of nuclear factor $\mathrm{\kappa B}$ ligand (RANKL) (Hsu et al. 1999; Wada et al. 2006), and macrophage colony-stimulating factor (Yoshida et al. 1990). $\mathrm{Ca}^{2+}$ signaling is known to play a key role in the differentiation of osteoclasts. Indeed, it has been shown that RANKL stimulates the generation of $\mathrm{Ca}^{2+}$ oscillations, which result in the calcineurin-mediated activation and nuclear localization of nuclear factor-activated T cells c1 (NFATc1), which in turn activates the gene transcription that regulates the terminal differentiation of these cells (Takayanagi et al. 2002). Following the $\mathrm{Ca}^{2+}$ oscillations, there is also an influx of $\mathrm{Ca}^{2+}$ on the basolateral side of osteoclasts, which is mediated by TRPV4, a $\mathrm{Ca}^{2+}$-permeable channel of the transient receptor potential family. It has been suggested that the oscillations and influx of $\mathrm{Ca}^{2+}$ together help to maintain the intracellular $\mathrm{Ca}^{2+}$ levels to ensure that NFATc1-regulated gene transcription (and hence osteoclast differentiation) is maintained (Masuyama et al. 2008).

It was also recently reported that TPC2 plays a key role in the differentiation of osteoclasts (Notomi et al. 2012, 2017). TPC2 was shown to be expressed by mouse bone marrow cells and the mouse osteoclast precursor cell line, RAW 264.7. In TPC2-knockdown cells, RANKL-regulated processes were reported to be inhibited, including the generation of the $\mathrm{Ca}^{2+}$ signals, and the nuclear localization of NFATc1 (Notomi et al. 2012). Furthermore, the TPC2 function was reported to be dependent on the amount of $\mathrm{Mg}^{2+}$, which (along with $\mathrm{Ca}^{2+}$ ) is stored in bone (Swaminathan 2003). Thus, whereas in normal $\mathrm{Mg}^{2+}$ conditions, TPC2 promoted osteoclast differentiation; when the level of $\mathrm{Mg}^{2+}$ was low, TPC2 inhibited this process. In addition, TPC2 was demonstrated to affect these changes by distinct mechanisms, such that it promoted and inhibited osteoclastogenesis via a $\mathrm{Ca}^{2+}$-dependent mechanism and via $\mathrm{PI}(3,5)$ $\mathrm{P}_{2}$-dependent changes in $\mathrm{Na}^{+}$(rather than in $\mathrm{Ca}^{2+}$ ), respectively (Notomi et al. 2017). This might be the first example of the dual action of TPC2 (i.e., demonstrating its ability to transport both $\mathrm{Ca}^{2+}$ and $\mathrm{Na}^{+}$) in the same cell type (i.e., in RAW 264.7 cells) when exposed to different extracellular environments.

\section{TPC-MEDIATED Ca ${ }^{2+}$ SIGNALING DURING THE DIFFERENTIATION OF ENDOTHELIAL AND EPITHELIAL CELLS}

The formation of new blood vessels from preexisting vessels (angiogenesis) is a key process during embryogenesis, and during the reproductive cycle of female mammals. Angiogenesis is also important during the repair and regeneration of damaged tissue, as well as in various diseases (Gupta and Zhang 2005). This process involves the proliferation, migration, and remodeling of endothelial cells from pre-existing blood vessels (Folkman and Shing 1992; Risau 1995), and it is regulated by vascular endothelial growth factor (VEGF) and its receptors, VEGFR1 and VEGFR2 (Michiels 2003). It has recently been shown both in vitro and in vivo that a VEGF/NAADP/TPC2/Ca ${ }^{2+}$ signaling cascade plays a key role in the formation of blood vessels (Favia et al. 2014). For example, treatment of human umbilical vein endothelial cells with trans-ned-19 or tpcn 2 shRNA inhibited the usual VEGF-stimulated release of $\mathrm{Ca}^{2+}$ and formation of capillary-like tubes. Furthermore, in intact mice, the VEGF-induced formation of blood vessels was inhibited by trans-ned-19 in C57BL/6 (wild-type) animals and it failed to occur at all in Tpcn $2^{-/-}$mutants (Favia et al. 2014).

Although there is currently no direct evidence that TPCs play a role in the differentiation of epithelial cells, NAADP has been shown to stimulate an increase in $\mathrm{Ca}^{2+}$ and promote the differentiation of human epidermal keratinocyte cells (Park et al. 2015). The latter was demonstrated by the effect of NAADP treatment on the level of expression of several protein markers for early and late keratinocyte differentiation, 
TPCs in Development and Differentiation

and the increase in activity of transglutaminases (Park et al. 2015), which are required for crosslinking proteins during terminal keratinocyte differentiation (Tharakan et al. 2010). The NAADP-stimulated $\mathrm{Ca}^{2+}$ signaling in these cells was shown to be inhibited by treatment with trans-ned-19, dipyridamole or bafilomycin, but was not affected by treatment with 8-bromocADPR (a cADPR inhibitor), xestospongin $\mathrm{C}$ (an $\mathrm{IP}_{3} \mathrm{R}$ inhibitor), or ryanodine at a RyR inhibitory concentration (Park et al. 2015). These data therefore indicate that TPCs might also play a key role in the differentiation of this specialized epithelial cell type.

\section{CONCLUDING REMARKS}

Here, we have reviewed what has been described so far about the role of NAADP/TPC/Ca ${ }^{2+}$ signaling during development and cellular differentiation. Tracking down the exact target or targets of NAADP, and identifying whether NAADP is the sole agonist of TPCs or not, as well as discovering whether TPCs conduct $\mathrm{Na}^{+}$ rather than $\mathrm{Ca}^{2+}$ is a matter of great interest for researchers in the $\mathrm{Ca}^{2+}$ signaling field. It is perhaps not surprising that a cation channel family with an evolutionary lineage such as the TPCs might have more than one agonist as well as a number of agonist-binding strategies (LinMoshier et al. 2014; Rahman et al. 2015; Feijóo-Bandin et al. 2017). The fact that TPCs have a somewhat promiscuous relationship with regard to the agonists that induce their opening, and the cations that they subsequently gate, in addition to their ability to act as a $\mathrm{Ca}^{2+}$ release trigger (Galione et al. 2009; Patel et al. 2010; Davis et al. 2012; Morgan et al. 2013), makes them a very interesting and challenging component of the $\mathrm{Ca}^{2+}$ signaling toolkit (Berridge et al. 2000) to study and understand, especially when it comes to the regulation of developmental and cellular differentiation. Furthermore, when considering the size and relative mobility of the acidic organelles that present TPCs to the cytosolic environment, this provides additional tantalizing evidence to suggest that they might be major players in intracellular $\mathrm{Ca}^{2+}$ signaling pathways. Indeed, endosomes and lysosomes along with closely associated ER/SR have been described as being a regulatory hub at the intersection of intracellular $\mathrm{Ca}^{2+}$ signaling (Marchant and Patel 2015; Perera and Zoncu 2016; Kilpatrick et al. 2017). In addition, while it is becoming clear that in some circumstances NAADP does appear to play a significant role in the $\mathrm{Ca}^{2+}$-mediated signaling pathways that orchestrate embryogenesis and differentiation, whether it does so via a TPC family member or some other target is (in many cases) still to be determined. Resolving these issues is essential for the role played by this pleiotropic channel family in key developmental events to be fully appreciated.

\section{ACKNOWLEDGMENTS}

Our work is supported by the HK RGC General Research Fund awards No. 16101714 and No. 16100115. We also acknowledge funding from the Hong Kong Innovation and Technology Commission (ITCPD/17-9).

\section{REFERENCES}

Aarhus R, Dickey DM, Graeff RM, Gee KR, Walseth TF, Lee HC. 1996. Activation and inactivation of $\mathrm{Ca}^{2+}$ release by NAADP $^{+}$. J Biol Chem 271: 8513-8516. doi:10.1074/jbc .271 .15 .8513

Albrieux M, Lee HC, Villaz M. 1998. Calcium signalling by cyclic ADP-ribose, NAADP, and inositol trisphosphate are involved in distinct functions in ascidian oocytes. $J$ Biol Chem 273: 14566-14574. doi:10.1074/jbc.273.23 14566

Aley PK, Mikolajczyk AM, Munz B, Churchill GC, Galione A, Berger F. 2010a. Nicotinic acid adenine dinucleotide phosphate regulates skeletal muscle differentiation via action at two-pore channels. Proc Natl Acad Sci 107: 19927 19932. doi:10.1073/pnas.1007381107

Aley PK, Noh HJ, Gao X, Tica AA, Brailoiu E, Churchill GC. 2010b. A functional role for nicotinic acid adenine dinucleotide phosphate in oxytocin-mediated contraction of uterine smooth muscle from rat. J Pharmacol Exp Ther 333: 726-735. doi:10.1124/jpet.110.165837

Aley PK, Singh N, Brailoiu GC, Brailoiu E, Churchill GC. 2013. Nicotinic acid adenine dinucleotide phosphate (NAADP) is a second messenger in muscarinic receptor-induced contraction of guinea pig trachea. $J$ Biol Chem 288: 10986-10993. doi:10.1074/jbc.M113.458620

Ambrosio AL, Boyle JA, Di Pietro SM. 2015. TPC2 mediates new mechanisms of platelet dense granule membrane dynamics through regulation of $\mathrm{Ca}^{2+}$ release. Mol Biol Cell 26: 3263-3274. doi:10.1091/mbc.e15-01-0058

Ambrosio AL, Boyle JA, Aradi Al E, Christian KA, Di Pietro SM. 2016. TPC2 controls pigmentation by regulating me- 
S.E. Webb et al.

lanosome $\mathrm{pH}$ and size. Proc Natl Acad Sci 113: 5622 5627. doi:10.1073/pnas.1600108113

Arndt L, Castonguay J, Arlt E, Meyer D, Hassan S, Borth H, Zierler S, Wennemuth G, Breit A, Biel M, et al. 2014. NAADP and the two-pore channel protein 1 participate in the acrosome reaction in mammalian spermatozoa. Mol Biol Cell 25: 948-964. doi:10.1091/mbc.E13-09-0523

Arredouani A, Ruas M, Collins SC, Parkesh R, Clough F, Pillinger T, Coltart G, Rietdorf K, Royle A, Johnson P, et al. 2015. Nicotinic acid adenine dinucleotide phosphate (NAADP) and endolysosomal two-pore channels modulate membrane excitability and stimulus-secretion coupling in mouse pancreatic $\beta$ cells. $J$ Biol Chem 290: 21376-21392. doi:10.1074/jbc.M115.671248

Asagiri M, Takayanagi H. 2007. The molecular understanding of osteoclast differentiation. Bone 40: 251-264. doi:10 .1016/j.bone.2006.09.023

Augustine GJ, Charlton MP, Smith SJ. 1987. Calcium action in synaptic transmitter release. Ann Rev Neurosci 10: 633 693. doi:10.1146/annurev.ne.10.030187.003221

Avila G, O'Connell KMS, Groom LA, Dirksen RT. 2001. $\mathrm{Ca}^{2+}$ release through ryanodine receptors regulates skeletal muscle L-type $\mathrm{Ca}^{2+}$ channel expression. J Biol Chem 276: 17732-17738. doi:10.1074/jbc.M009685200

Baker KD, Edwards TM, Rickard NS. 2013. The role of intracellular calcium stores in synaptic plasticity and memory consolidation. Neurosci Biobehav Rev 37: 1211-1239. doi:10.1016/j.neubiorev.2013.04.011

Bandtlow CE, Schmidt MF, Hassinger TD, Schwab ME, Kater SB. 1993. Role of intracellular calcium in NI-35evoked collapse of neuronal growth cones. Science 259: 80-83. doi:10.1126/science.8418499

Basarsky TA, Parpura V, Haydon PG. 1994. Hippocampal synaptogenesis in cell culture: Developmental time course of synapse formation, calcium influx, and synaptic protein distribution. J Neurosci 14: 6402-6411. doi:10.1523/ jneurosci.14-11-06402.1994

Bedell VM, Westcot SE, Ekker SC. 2011. Lessons from morpholino-based screening in zebrafish. Brief Funct Genomics 10: 181-188. doi:10.1093/bfgp/elr021

Berg I, Potter BVL, Mayr GW, Guse AH. 2000. Nicotinic acid adenine dinucleotide phosphate $\left(\mathrm{NAADP}^{+}\right)$is an essential regulator of T-lymphocyte $\mathrm{Ca}^{2+}$ signalling. J Cell Biol 150: 581-588. doi:10.1083/jcb.150.3.581

Berridge MJ. 1987. Inositol trisphosphate and diacylglycerol: Two interacting second messengers. Ann Rev Biochem 56: 159-193. doi:10.1146/annurev.bi.56.070187.001111

Berridge MJ. 1998. Neuronal calcium signalling. Neuron 21: 13-26. doi:10.1016/S0896-6273(00)80510-3

Berridge MJ, Irvine RF. 1984. Inositol trisphosphate, a novel second messenger in cellular signal transduction. Nature 312: 315-321. doi:10.1038/312315a0

Berridge MJ, Lipp P, Bootman MD. 2000. The versatility and universality of calcium signaling. Nat Rev Mol Cell Biol 1: 11-21. doi:10.1038/35036035

Berridge MJ, Bootman MD, Roderick HL. 2003. Calcium signalling: Dynamics, homeostasis and remodelling. Nat Rev Mol Cell Biol 4: 517-529. doi:10.1038/nrm1155

Bezin S, Charpentier G, Lee HC, Baux G, Fossier P, Cancela JM. 2008. Regulation of nuclear $\mathrm{Ca}^{2+}$ signalling by translocation of the $\mathrm{Ca}^{2+}$ messenger synthesizing enzyme
ADP-ribosyl cyclase during neuronal depolarization. $J$ Biol Chem 283: 27859-27870. doi:10.1074/jbc.M8 04701200

Blum M, De Robertis EM, Wallingford JB, Niehrs C. 2015. Morpholinos: Antisense and sensibility. Dev Cell 35: 145 149. doi:10.1016/j.devcel.2015.09.017

Bolsover SR. 2005. Calcium signalling in growth cone migration. Cell Calcium 37: 395-402. doi:10.1016/j.ceca .2005 .01 .007

Boyle WJ, Simonet WS, Lacey DL. 2003. Osteoclast differentiation and activation. Nature 423: 337-342. doi:10 $.1038 /$ nature 01658

Brailoiu E, Hoard JL, Filipeanu CM, Brailoiu GC, Dun SL, Patel S, Dun NJ. 2005. Nicotinic acid adenine dinucleotide phosphate potentiates neurite outgrowth. J Biol Chem 280: 5646-5650. doi:10.1074/jbc.M408746200

Brailoiu E, Churamani D, Pandey V, Brailoiu GC, Tuluc F, Patel S, Dun NJ. 2006. Messenger-specific role for nicotinic acid adenine dinucleotide phosphate in neuronal differentiation. J Biol Chem 281: 15923-15928. doi:10 $.1074 /$ jbc.M602249200

Brailoiu GC, Brailoiu E, Parkesh R, Galione A, Churchill GC Patel S, Dun NJ. 2009. NAADP-mediated channel "chatter" in neurons of the rat medulla oblongata. Biochem J 419: 91-99. doi:10.1042/BJ20081138

Brailoiu E, Rahman T, Churamani D, Prole DL, Brailoiu GC, Hooper R, Taylor CW, Patel S. 2010. An NAADP-gated two-pore channel targeted to the plasma membrane uncouples triggering from amplifying $\mathrm{Ca}^{2+}$ signals. J Biol Chem 285: 38511-38516. doi:10.1074/jbc.M110.162073

Brennan C, Mangoli M, Dyer CE, Ashworth R. 2005. Acetylcholine and calcium signalling regulates muscle fibre formation in the zebrafish embryo. J Cell Sci 118: 51815190. doi: $10.1242 /$ jcs. 02625

Brini M, Cali T, Ottolini D, Carafoli E. 2014. Neuronal calcium signalling: function and dysfunction. Cell Mol Life Sci 71: 2787-2814. doi:10.1007/s00018-013-1550-7

Calcraft PJ, Arredouani A, Ruas M, Pan Z, Cheng X, Hao X, Tang J, Rietdorf K, Teboul L, Chuang KT, et al. 2009. NAADP mobilizes calcium from acidic organelles through two-pore channels. Nature 459: 596-600. doi: $10.1038 /$ nature08030

Cancela JM, Churchill GC, Galione A. 1999. Coordination of agonist-induced $\mathrm{Ca}^{2+}$-signalling patterns by NAADP in pancreatic acinar cells. Nature 398: 74-76. doi:10.1038/ 18032

Cang C, Zhou Y, Navarro B, Seo Y, Aranda K, Shi L, Battaglia-Hsu S, Nissim I, Clapham DE, Ren D. 2013. mTOR regulates lysosomal ATP-sensitive two-pore $\mathrm{Na}^{+}$channels to adapt to metabolic state. Cell 152: 778-790. doi:10.1016/j.cell.2013.01.023

Cang C, Aranda K, Ren D. 2014. A non-inactivating highvoltage-activated two-pore $\mathrm{Na}^{+}$channel that supports ultra-long action potentials and membrane bistability. Nat Commun 5: 5015. doi:10.1038/ncomms6015

Capel RA, Bolton EL, Lin WK, Aston D, Wang Y, Liu W, Wang X, Burton RA, Bloor-Young D, Shade KT, et al. 2015. Two-pore channels (TPC2s) and nicotinic acid adenine dinucleotide phosphate (NAADP) at lysosomalsarcoplasmic reticular junctions contribute to acute and chronic $\beta$-adrenoceptor signaling in the heart. $J$ Biol Chem 290: 30087-30098. doi:10.1074/jbc.M115.684076 
Cárdenas C, Liberona JL, Molgó J, Colasante C, Mignery GA, Jaimovich E. 2005. Nuclear inositol 1,4,5-trisphosphate receptors regulate local $\mathrm{Ca}^{2+}$ transients and modulate cAMP response element binding protein phosphorylation. J Cell Sci 118: 3131-3140. doi:10.1242/jcs.02446

Carrasco MA, Riveros N, Ríos J, Müller M, Torres F, Pineda J, Lantadilla S, Jaimovich E. 2003. Depolarization-induced slow calcium transients activate early genes in skeletal muscle cells. Am J Physiol Cell Physiol 284: C1438C1447. doi:10.1152/ajpcell.00117.2002

Chambers TJ. 2000. Regulation of the differentiation and function of osteoclasts. J Pathol 192: 4-13. doi:10.1002/ 1096-9896(2000)

Cheng X, Zhang X, Gao Q, Samie MA, Azar M, Tsang WL, Dong L, Sahoo N, Li X, Zhuo Y, et al. 2014. The intracellular $\mathrm{Ca}^{2+}$ channel MCOLN1 is required for sarcolemma repair to prevent muscular dystrophy. Nat Med 20: 11871192. doi:10.1038/nm.3611

Cheng X, Zhang X, Yu L, Xu H. 2015. Calcium signaling in membrane repair. Semin Cell Dev Biol 45: 24-31. doi:10 .1016/j.semcdb.2015.10.031

Cheung CY, Webb SE, Love DR, Miller AL. 2011. Visualization, characterization and modulation of calcium signaling during the development of slow muscle cells in intact zebrafish embryos. Int J Dev Biol 55: 153-174. doi:10 $.1387 / \mathrm{ijdb} .103160 \mathrm{cc}$

Churchill GC, Okada Y, Thomas JM, Genazzani AA, Patel S, Galione A. 2002. NAADP mobilizes $\mathrm{Ca}^{2+}$ from reserve granules, lysosome-related organelles, in sea urchin eggs. Cell 111: 703-708. doi:10.1016/S0092-8674(02)01082-6

Collins TP, Bayliss R, Churchill GC, Galione A, Terrar DA. 2011. NAADP influences excitation-contraction coupling by releasing calcium from lysosomes in atrial myocytes. Cell Calcium 50: 449-458. doi:10.1016/j.ceca.2011 .07 .007

Davis LC, Morgan AJ, Chen JL, Sneed CM, Bloor-Young D, Shenderov E, Stanton-Humphreys MN, Conway SJ, Churchill GC, Parrington J, et al. 2012. NAADP activates two-pore channels on T cell cytolytic granules to stimulate exocytosis and killing. Curr Biol 22: 2331-2337. doi:10.1016/j.cub.2012.10.035

Devoto SH, Melançon E, Eisen JS, Westerfield M. 1996. Identification of separate slow and fast muscle precursor cells in vivo, prior to somite formation. Development 122: 3371-3380.

Dodge FA Jr, Rahamimoff R. 1967. Co-operative action of calcium ions in transmitter release at the neuromuscular junction. J Physiol 193: 419-432. doi:10.1113/jphysiol .1967.sp008367

Espositio B, Gambara G, Lewis AM, Palombi F, D’Alessio A, Taylor LX, Genazzani AA, Ziparo E, Galione A, Churchill GC, et al. 2011. NAADP links histamine H1 receptors to secretion of von Willebrand factor in human endothelial cells. Blood 117: 4968-4977. doi:10.1182/blood-2010-02266338

Fameli N, Ogunbayo OA, van Breemen C, Evans AM. 2014. Cytoplasmic nanojunctions between lysosomes and sarcoplasmic reticulum are required for specific calcium signaling. F1000Res 3: 93. doi:10.12688/f1000research .3720 .1

Favia A, Desideri M, Gambara G, D'Alessio A, Ruas M, Esposito B, Del Bufalo D, Parrington J, Ziparo E, Palombi
F, et al. 2014. VEGF-induced neoangiogenesis is mediated by NAADP and two-pore channel-2-dependent $\mathrm{Ca}^{2+}$ signalling. Proc Natl Acad Sci 111: E4706-E4715. doi:10 $.1073 /$ pnas.1406029111

Feijóo-Bandin S, García-Vence M, García-Rúa V, Roselló E Portoles B, Rivera M, González-Juanatey JR, Lago F. 2017. Two-pore channels (TPCs): Novel voltage-gated ion channels with pleiotropic functions. Channels 11: 2033. doi:10.1080/19336950.2016.1213929

Feng ZP, Grigoriev N, Munno D, Lukowiak K, MacVicar BA, Goldberg JI, Syed N. 2002. Development of $\mathrm{Ca}^{2+}$ hotspots between Lymnaea neurons during synaptogenesis. J Physiol 539: 53-65. doi:10.1113/jphysiol.2001.013125

Ferrari MB, Rohrbough J, Spitzer NC. 1996. Spontaneous calcium transients regulate myofibrillogenesis in embryonic Xenopus myocytes. Dev Biol 178: 484-497. doi:10 $.1006 /$ dbio.1996.0233

Ferrari MB, Ribbeck K, Hagler DJ, Spitzer NC. 1998. A calcium signaling cascade essential for myosin thick filament assembly in Xenopus myocytes. J Cell Biol 141: 13491356. doi:10.1083/jcb.141.6.1349

Fleischer S, Ogunbunmi EM, Dixon MC, Fleer EAM. 1985. Localization of $\mathrm{Ca}^{2+}$ release channels with ryanodine in junctional terminal cisternae of sarcoplasmic reticulum of fast skeletal muscle. Proc Natl Acad Sci 82: 7256-7259. doi:10.1073/pnas.82.21.7256

Folkman J, Shing Y. 1992. Angiogenesis. J Biol Chem 267: 10931-10934.

Galione A. 2015. A primer of NAADP-mediated $\mathrm{Ca}^{2+}$ signalling: From sea urchin eggs to mammalian cells. Cell Calcium 58: 27-47. doi:10.1016/j.ceca.2014.09.010

Galione A, Evans AM, Ma J, Parrington J, Arredouani A, Cheng X, Zhu MX. 2009. The acid test: The discovery of two-pore channels (TPCs) as NAADP-gated endolysosomal Ca ${ }^{2+}$ release channels. Pflugers Arch Eur J Physiol 458: 869-876. doi:10.1007/s00424-009-0682-y

Gambara G, Billington RA, Debidda M, D’Alessio A, Palombi F, Ziparo E, Genazzani AA, Filippini A. 2008 NAADP-induced $\mathrm{Ca}^{2+}$ signalling in response to endothelin is via the receptor subtype $B$ and requires the integrity of lipid rafts/caveolae. J Cell Physiol 216: 396-404. doi:10 $.1002 /$ jcp. 21407

Gasperini RJ, Pavez M, Thompson AC, Mitchell CB, Hardy H, Young KM, Chilton JK, Foa L. 2017. How does calcium interact with the cytoskeleton to regulate growth cone motility during axon pathfinding? Mol Cell Neurosci 84: 29-35. doi:10.1016/j.mcn.2017.07.006

Ghosh A, Ginty DD, Bading H, Greenberg ME. 1994. Calcium regulation of gene expression in neuronal cells. $J$ Neurobiol 25: 294-303. doi:10.1002/neu.480250309

Gibbs ME, Gibbs CL, Ng KT. 1979. The influence of calcium on short-term memory. Neurosci Lett 14: 355-360. doi:10 .1016/0304-3940(79)96174-3

Gruol D, Manto M, Haines D. 2012. $\mathrm{Ca}^{2+}$ signalling in cerebellar Purkinje neurons-Editorial. Cerebellum 11: 605-608. doi:10.1007/s12311-012-0404-4

Gupta K, Zhang J. 2005. Angiogenesis: A curse or cure? Postgrad Med J 81: 236-242. doi:10.1136/pgmj.2004 .023309

Guse AH. 2009. Second messenger signaling: Multiple receptors for NAADP. Curr Biol 19: R522. 
S.E. Webb et al.

Guse AH. 2012. Linking NAADP to ion channel activity: A unifying hypothesis. Sci Signal 5: pe18. doi:10.1126/scisig nal.2002890

Guse AH, Diercks BP. 2018. Integration of nicotinic acid adenine dinucleotide phosphate (NAADP)-dependent calcium signaling. J Physiol 596: 2735-2743. doi:10 $.1113 / J P 275974$

Guse A, Lee HC. 2008. NAADP: A universal $\mathrm{Ca}^{2+}$ trigger. $\mathrm{Sci}$ Signal 1: re10. doi:10.1126/scisignal.144re10

Harvey AM, MacIntosh FC. 1940. Calcium and synaptic transmission in a sympathetic ganglion. J Physiol 97: 408-416. doi:10.1113/jphysiol.1940.sp003818

Heidemann AC, Schipke CG, Kettenmann H. 2005 Extracellular application of nicotinic acid adenine dinucleotide phosphate induces $\mathrm{Ca}^{2+}$ signalling in astrocytes in situ. J Biol Chem 280: 35630-35640. doi:10.1074/jbc .M507338200

Henley J, Poo MM. 2004. Guiding neuronal growth cones by $\mathrm{Ca}^{2+}$ signals: During axon pathfinding in the developing nervous system, spatiotemporal patterns of $\mathrm{Ca}^{2+}$ signals can govern growth cone extension and steering-By symmetric versus asymmetric regulation of cytoskeletal and membrane dynamics. Trends Cell Biol 14: 320-330. doi:10.1016/j.tcb.2004.04.006

Hertle DN, Yeckel MF. 2007. Distribution of inositol-1,4,5 trisphosphate receptor isotypes and ryanodine receptor isotypes during maturation of the rat hippocampus. Neurosci 150: 625-638. doi:10.1016/j.neuroscience.2007.09 .058

Hockey LN, Kilpatrick BS, Eden ER, Lin-Moshier Y, Brailoiu GC, Brailoiu E, Futter CE, Schapira AH, Marchant JS, Patel S. 2015. Dysregulation of lysosomal morphology by pathogenic LRRK2 is corrected by TPC2 inhibition. J Cell Sci 128: 232-238. doi:10.1242/jcs. 164152

Hsu H, Lacey DL, Dunstan CR, Solovyev I, Colombero A, Timms E, Tan HL, Elliott G, Kelley MJ, Sarosi I, et al. 1999. Tumor necrosis factor receptor family member RANK mediates osteoclast differentiation and activation induced by osteoprotegerin ligand. Proc Natl Acad Sci 96 : 3540-3545. doi:10.1073/pnas.96.7.3540

Jaimovich E, Carrasco MA. 2002. $\mathrm{IP}_{3}$ dependent $\mathrm{Ca}^{2+}$ signals in muscle cells are involved in regulation of gene expression. Biol Res 35: 195-202. doi:10.4067/S071697602002000200010

Jha A, Ahuja M, Patel S, Brailoiu E, Muallem S. 2014. Convergent regulation of the lysosomal two-pore channel-2 by $\mathrm{Mg}^{2+}$, NAADP, $\mathrm{PI}(3,5) \mathrm{P}_{2}$ and multiple protein kinases. EMBO J 33: 501-511. doi:10.1002/embj.201387035

Kawamoto EM, Vivar C, Camandola S. 2012. Physiology and pathology of calcium signalling in the brain. Front Pharmacol 3: 61. doi:10.3389/fphar.2012.00061

Keller R. 2005. Cell migration during gastrulation. Curr Opin Cell Biol 17: 533-541. doi:10.1016/j.ceb.2005.08.006

Kelu JJ, Chan HL, Webb SE, Cheng AH, Ruas M, Parrington J, Galione A, Miller AL. 2015. Two-pore channel 2 activity is required for slow muscle cell-generated $\mathrm{Ca}^{2+}$ signaling during myogenesis in intact zebrafish. Int J Dev Biol 59: 313-325. doi:10.1387/ijdb.150206am

Kelu JJ, Webb SE, Parrington J, Galione A, Miller AL. 2017. $\mathrm{Ca}^{2+}$ release via two-pore channel type 2 (TPC2) is required for slow muscle cell myofibrillogenesis and myo- tomal patterning in intact zebrafish embryos. Dev Biol 425: 109-129. doi:10.1016/j.ydbio.2017.03.031

Kelu JJ, Webb SE, Galione A, Miller AL. 2018. TPC2-mediated $\mathrm{Ca}^{2+}$ signaling is required for the establishment of synchronized activity in developing zebrafish primary motor neurons. Dev Biol 438: 57-68. doi:10.1016/j .ydbio.2018.02.011

Kilpatrick BS, Eden ER, Hockey LN, Yates E, Futter CE, Patel S. 2017. An endosomal NAADP-sensitive two-pore $\mathrm{Ca}^{2+}$ channel regulates ER-endosome membrane contact sites to control growth factor signaling. Cell Rep 18: 16361645. doi:10.1016/j.celrep.2017.01.052

Kinnear NP, Boittin FX, Thomas JM, Galione A, Evans AM. 2004. Lysosome-sarcoplasmic reticulum junctions: A trigger zone for calcium signalling by nicotinic acid adenine dinucleotide phosphate and endothelin-1. J Biol Chem 279: 54319-54326. doi:10.1074/jbc.M406132200

Kintzer AF, Stroud RM. 2018. On the structure and mechanism of two-pore channels. FEBS J 285: 233-243. doi:10 $.1111 /$ febs.14154

Komuro H, Rakic P. 1992. Selective role of N-type calcium channels in neuronal migration. Science 257: 806-809. doi:10.1126/science. 1323145

Lamont MG, Weber JT. 2012. The role of calcium in synaptic plasticity and motor learning in the cerebellar cortex. Neurosci Biobehav Rev 36: 1153-1162. doi:10.1016/j neubiorev.2012.01.005

Lankford KL, Letourneau PC. 1989. Evidence that calcium may control neurite outgrowth by regulating the stability of actin filaments. J Cell Biol 109: 1229-1243. doi:10 $.1083 /$ jcb.109.3.1229

Lee HC, Aarhus R. 1995. A derivative of NADP mobilizes calcium stores insensitive to inositol trisphosphate and cyclic ADP-ribose. J Biol Chem 270: 2152-2157. doi:10 $.1074 / \mathrm{jbc} .270 .5 .2152$

Lee MSY, Beck RMD. 2015. Mammalian evolution: A Jurassic spark. Current Biol 25: R759-R761. doi:10.1016/j.cub .2015 .07 .008

Lim D, Kyozuka K, Gragnaniello G, Carafoli E, Santella L. 2001. NAADP ${ }^{+}$initiates the $\mathrm{Ca}^{2+}$ response during fertilization of starfish oocytes. FASEB J 15: 2257-2267. doi:10 .1096/fj.01-0157com

Lin PH, Duann P, Komazaki S, Park KH, Li H, Sun M, Sermersheim M, Gumpper K, Parrington J, Galione A, et al. 2015. Lysosomal two-pore channel subtype 2 (TPC2) regulates skeletal muscle autophagic signaling. $J$ Biol Chem 290: 3377-3389. doi:10.1074/jbc.M114 .608471

Lin-Moshier Y, Keebler MV, Hooper R, Boulware MJ, Liu X, Churamani D, Abood ME, Walseth TF, Brailoiu E, Patel S, et al. 2014. The two-pore channel (TPC) interactome unmasks isoform-specific roles for TPCs in endolysosomal morphology and cell pigmentation. Proc Natl Acad Sci USA 111: 13087-13092. doi:10.1073/pnas.1407004111

Lu B, Zhang Q, Wang H, Wang Y, Nakayama M, Ren D. 2010. Extracellular calcium controls background current and neuronal excitability via an UNC79-UNC80NALCN cation channel complex. Neuron 68: 488-499. doi:10.1016/j.neuron.2010.09.014

Marchant JS, Patel S. 2015. Two-pore channels at the intersection of endolysosomal membrane traffic. Biochem Soc Trans 43: 434-441. doi:10.1042/BST20140303 
Masgrau R, Churchill GC, Morgan AJ, Ashcroft SJH, Galione A. 2003. NAADP: A new second messenger for glucose-induced $\mathrm{Ca}^{2+}$ responses in clonal pancreatic $\beta$ cells. Curr Biol 13: 247-251. doi:10.1016/S0960-9822 (03)00041-1

Masuyama R, Vriens J, Voets T, Karashima Y, Owsianik G, Vennekens R, Lieben L, Torrekens S, Moermans K, Van den Bosch A, et al. 2008. TRPV4-mediated calcium influx regulates terminal differentiation of osteoclasts. Cell Metab 8: 257-265. doi:10.1016/j.cmet.2008.08.002

Michiels C. 2003. Endothelial cell functions. J Cell Physiol 196: 430-443. doi:10.1002/jcp.10333

Moccia F, Lim D, Kyozuka K, Santella L. 2004. NAADP triggers the fertilization potential in starfish oocytes. Cell Calcium 36: 515-524. doi:10.1016/j.ceca.2004.05.004

Moccia F, Billington RA, Santella L. 2006. Pharmacological characterization of NAADP-induced $\mathrm{Ca}^{2+}$ signals in starfish oocytes. Biochem Biophys Res Commun 348: 329336. doi:10.1016/j.bbrc.2006.05.157

Morgan AJ, Davis LC, Wagner SK, Lewis AM, Parrington J, Churchill GC, Galione A. 2013. Bidirectional $\mathrm{Ca}^{2+}$ signaling occurs between the endoplasmic reticulum and acidic organelles. J Cell Biol 200: 789-805. doi:10.1083/jcb 201204078

Muto A, Kawakami K. 2011. Imaging functional neural circuits in zebrafish with a new GCaMP and the Gal4FFUAS system. Commun Integr Biol 4: 566-568. doi:10 $.4161 / \mathrm{cib} .15848$

Muto A, Ohkura M, Kotani T, Higashijima SI, Nakai J, Kawakami K. 2011. Genetic visualization with an improved GCaMP calcium indicator reveals spatiotemporal activation of the spinal motor neurons in zebrafish. Proc Natl Acad Sci 108: 5425-5430. doi:10.1073/pnas .1000887108

Nakashima T, Hayashi M, Takayanagi H. 2012. New insights into osteoclastogenic signalling mechanisms. Trends Endocrinol Metab 23: 582-590. doi:10.1016/j.tem.2012.05 .005

Navazio I, Bewell MA, Siddiqua A, Dickinson GD, Galione A, Sanders D. 2000. Calcium release from the endoplasmic reticulum of higher plants elicited by the NADP metabolite nicotinic acid adenine dinucleotide phosphate. Proc Natl Acad Sci 97: 8693-8698. doi:10.1073/pnas .140217897

Naylor EA, Arredouani SR, Vasudevan AM, Lewis R, Parkesh A, Mizote D, Rosen JM, Thomas M, Izumi A, Ganesan A, et al. 2009. Identification of a chemical probe for NAADP by virtual screening. Nat Chem Biol 5: 220-226. doi:10.1038/nchembio. 150

Nguyen ONP, Grimm C, Schneider LS, Chao YK, Atzberger C, Bartel K, Watermann A, Ulrich M, Mayr D, WahlSchott C, et al. 2017. Two-pore channel function is crucial for the migration of invasive cancer cells. Cancer Res 77: 1427-1438. doi:10.1158/0008-5472.CAN-16-0852

Notomi T, Ezura Y, Noda M. 2012. Identification of twopore channel 2 as a novel regulator of osteoclastogenesis. J Biol Chem 287: 35057-35064. doi:10.1074/jbc.M111 .328930

Notomi T, Kuno M, Hiyama A, Nozaki T, Ohura K, Ezura Y, Noda M. 2017. Role of lysosomal channel protein TPC2 in osteoclast differentiation and bone remodeling under normal and low-magnesium conditions. J Biol Chem 292: 20998-21010. doi:10.1074/jbc.M117.780072

Numakawa T, Nakayama H, Suzuki S, Kubo T, Nara F, Numakawa Y, Yokomaku D, Araki T, Ishimoto T, Ogura A, et al. 2003. Nerve growth factor-induced glutamate release is via 75 receptor, ceramide, and $\mathrm{Ca}^{2+}$ from ryanodine receptor in developing cerebellar neurons. J Biol Chem 278: 41259-41269. doi:10.1074/jbc.M304409200

Ogunbayo OA, Zhu Y, Shen B, Agbani E, Li J, Ma J, Zhu MX, Evans AM. 2015. Organelle-specific subunit interactions of the vertebrate two-pore channel family. J Biol Chem 290: 1086-1095. doi:10.1074/jbc.M114.610493

Ogunbayo OA, Duan J, Xiong J, Wang Q, Feng X, Ma J, Zhu MX, Evans AM. 2018. mTORC1 controls lysosomal $\mathrm{Ca}^{2+}$ release through the two-pore channel TPC2. Sci Signal 11: eaao5775. doi:10.1126/scisignal.aao5775

Park KH, Kim KN, Park DR, Jang KY, Kim UH. 2015. Role of nicotinic acid adenine dinucleotide phosphate (NAADP) in keratinocyte differentiation. J Invest Dermatol 135: 1692-1694. doi:10.1038/jid.2015.43

Patel S, Marchant J, Brailoiu E. 2010. Two-pore channels: Regulation by NAADP and customized roles in triggering calcium signals. Cell Calcium 47: 480-490. doi:10.1016/j .ceca.2010.05.001

Patel S, Churamani D, Brailoiu E. 2017. NAADP-evoked $\mathrm{Ca}^{2+}$ signals through two-pore channel-1 require arginine residues in the first S4-S5 linker. Cell Calcium 68: 1-4. doi:10.1016/j.ceca.2017.09.003

Penny CJ, Kilpatrick BS, Eden ER, Patel S. 2015. Coupling acidic organelles with the ER through $\mathrm{Ca}^{2+}$ microdomains at membrane contact sites. Cell Calcium 58: 387396. doi:10.1016/j.ceca.2015.03.006

Perera RM, Zoncu R. 2016. The lysosome as a regulatory hub. Anпu Rev Cell Dev Biol 32: 223-253. doi:10.1146/ annurev-cellbio-111315-125125

Powell JA, Carrasco MA, Adams DS, Drouet B, Rios J, Müller M, Estrada M, Jaimovich E. 2001. $\mathrm{IP}_{3}$ receptor function and localization in myotubes: An unexplored $\mathrm{Ca}^{2+}$ signaling pathway in skeletal muscle. J Cell Sci 114: 3673-3683.

Rahman T, Cai X, Brailoiu GC, Abood ME, Brailoiu E, Patel S. 2015. Two-pore channels provide insight into the evolution of voltage-gated $\mathrm{Ca}^{2+}$ and $\mathrm{Na}^{+}$channels. Sci Signal 7: ra109 doi:10.1126/scisignal.2005450

Ramos I, Reich A, Wessel GM. 2014. Two-pore channels function in calcium regulation in sea star oocytes and embryos. Development 141: 4598-4609. doi:10.1242/dev .113563

Ringer S. 1882. Concerning the influence exerted by each of the constituents of the blood on the contraction of the ventricle. J Physiol (Lond) 3: 380-393. doi:10.1113/jphy siol.1882.sp000111

Risau W. 1995. Differentiation of endothelium. FASEB J 9: 926-933. doi:10.1096/fasebj.9.10.7615161

Robu ME, Larson JD, Nasevicius A, Beiraghi S, Brenner C, Farber SA, Ekker SC. 2007. p53 activation by knockdown technologies. PLoS Genet 3: e78. doi:10.1371/journal .pgen.0030078

Rønn LCB, Dissing S, Holm A, Berezin V, Bock E. 2002. Increased intracellular calcium is required for neurite outgrowth induced by a synthetic peptide ligand of NCAM. 
S.E. Webb et al.

FEBS Lett 518: 60-66. doi:10.1016/S0014-5793(02) 02644-3

Rosenberg SS, Spitzer NC. 2011. Calcium signaling in neuronal development. Cold Spring Harb Perspect Biol 3: a004259. doi:10.1101/cshperspect.a004259

Roussel C, Erneux T, Schiffmann SN, Gall D. 2006. Modulation of neuronal excitability by intracellular calcium buffering: From spiking to bursting. Cell Calcium 39: 455-466. doi:10.1016/j.ceca.2006.01.004

Ruas M, Davis LC, Chen CC, Morgan AJ, Chuang KT, Walseth TF, Grimm C, Garnham C, Powell T, Platt N, et al. 2015. Expression of $\mathrm{Ca}^{2+}$-permeable two-pore channels rescues NAADP signalling in TPC-deficient cells. EMBO J 34: 1743-1758. doi:10.15252/embj.201490009

Rybalchenko V, Ahuja M, Coblentz J, Churamani D, Patel S, Kiselyov K, Muallem S. 2012. Membrane potential regulates nicotinic acid adenine dinucleotide phosphate (NAADP) dependence of the $\mathrm{pH}$ - and $\mathrm{Ca}^{2+}$-sensitive organellar two-pore channel TPC1. J Biol Chem 287: 20407-20416. doi:10.1074/jbc.M112.359612

Saint-Amant L, Drapeau P. 1998. Time course of the development of motor behaviors in the zebrafish embryo. $J$ Neurobiol 37: 622-632. doi:10.1002/(SICI)1097-4695 (199812)37:4<622::AID-NEU10>3.0.CO;2-S

Santella L, Kyozuka K, Genazzani AA, De Riso L, Carafoli E. 2000. Nicotinic acid adenine dinucleotide phosphate-induced $\mathrm{Ca}^{2+}$ release: Interactions among distinct $\mathrm{Ca}^{2+}$ mobilizing mechanisms in starfish oocytes. J Biol Chem 275: 8301-8306. doi:10.1074/jbc.275.12.8301

Santulli G, Nakashima R, Yuan Q, Marks AR. 2017. Intracellular calcium release channels: an update. J Physiol 595: 3041-3051. doi:10.1113/JP272781

She J, Guo J, Chen Q, Zeng W, Jiang Y, Bai X. 2018. Structural insights into the voltage and phospholipid activation of the mammalian TPC1 channel. Nature 556: 130-134. doi:10.1038/nature26139

Simons TJB. 1988. Calcium and neuronal function. Neurosurg Rev 11: 119-129. doi:10.1007/BF01794675

Singaravelu K, Deitmer JW. 2006. Calcium mobilization by nicotinic acid adenine dinucleotide phosphate (NAADP) in rat astrocytes. Cell Calcium 39: 143-153. doi:10.1016/j .ceca.2005.10.001

Stainier DY, Raz E, Lawson ND, Ekker SC, Burdine RD, Eisen JS, Ingham PW, Schulte-Merker S, Yelon D, Weinstein BM, et al. 2017. Guidelines for morpholino use in zebrafish. PLoS Genet 13: e1007000. doi:10.1371/journal .pgen.1007000

Stiber JA, Tabatabaei N, Hawkins AF, Hawke T, Worley PF, Williams RS, Rosenberg P. 2005. Homer modulates NFAT-dependent signaling during muscle differentiation. Dev Biol 287: 213-224. doi:10.1016/j.ydbio.2005 .06 .030

Suárez-Cortés P, Gambara G, Favia A, Palombi F, Alano P, Filippini A. 2017. Ned-19 inhibition of parasite growth and multiplication suggests a role for NAADP mediated signalling in the asexual development of Plasmodium falciparum. Malar J 16: 366. doi:10.1186/s12936-0172013-7

Südhof TC. 2012. Calcium control of neurotransmitter release. Cold Spring Harb Perspect Biol 4: a011353. doi:10 $.1101 /$ cshperspect.a011353
Swaminathan R. 2003. Magnesium metabolism and its disorders. Clin Biochem Rev 24: 47-66.

Takayanagi H, Kim S, Koga T, Nishina H, Isshiki M, Yoshida H, Saiura A, Isobe M, Yokochi T, Inoue J, et al. 2002. Induction and activation of the transcription factor NFATc1 (NFAT2) integrate RANKL signaling in terminal differentiation of osteoclasts. Dev Cell 3: 889-901. doi:10.1016/S1534-5807(02)00369-6

Takei K, Shin RM, Inoue T, Kato K, Mikoshiba K. 1998. Regulation of nerve growth mediated by inositol 1,4,5trisphosphate receptors in growth cones. Science 282: 1705-1708. doi:10.1126/science.282.5394.1705

Tam T, Mathews E, Snutch TP, Schafer WR. 2000. Voltagegated calcium channels direct neuronal migration in Caenorhabditis elegans. Dev Biol 226: 104-117. doi:10.1006/ dbio.2000.9854

Teitelbaum SL. 2000. Bone resorption by osteoclasts. Science 289: 1504-1508. doi:10.1126/science.289.5484.1504

Teitelbaum SL. 2007. Osteoclasts: What do they do and how do they do it? Am J Pathol 170: 427-435. doi:10.2353/ ajpath.2007.060834

Tharakan S, Pontiggia L, Biedermann T, Böttcher-Haberzeth S, Schiestl C, Reichmann E, Meuli M. 2010. Transglutaminases, involucrin, and loricrin as markers of epidermal differentiation in skin substitutes derived from human sweat gland cells. Pediatr Surg Int 26: 71-77. doi:10.1007/s00383-009-2517-5

Tu MK, Levin JB, Hamilton AM, Borodinsky LN. 2016. Calcium signaling in skeletal muscle development, maintenance and regeneration. Cell Calcium 59: 91-97. doi:10 .1016/j.ceca.2016.02.005

Tugba Durlu-Kandilci N, Ruas M, Chuang KT, Brading A, Parrington J, Galione A. 2010. TPC2 proteins mediate nicotinic acid adenine dinucleotide phosphate (NAADP)- and agonist-evoked contractions of smooth muscle. J Biol Chem 285: 24925-24932. doi:10.1074/jbc .M110.129833

Udagawa N, Takahashi N, Akatsu T, Tanaka H, Sasaki T, Nishihara T, Koga T, Martin J, Suda T. 1990. Origin of osteoclasts: Mature monocytes and macrophages are capable of differentiating into osteoclasts under a suitable microenvironment prepared by bone marrow-derived stromal cells. Proc Natl Acad Sci 87: 7260-7264. doi:10 $.1073 /$ pnas.87.18.7260

Valdés JA, Hidalgo J, Galaz JL, Puentes N, Silva M, Jaimovich E, Carrasco MA. 2007. NF- $\kappa$ B activation by depolarization of skeletal muscle cells depends on ryanodine and $\mathrm{IP}_{3}$ receptor-mediated calcium signals. Am J Physiol Cell Physiol 292: C1960-C1970. doi:10.1152/ajpcell.00320 .2006

Vasudevan SR, Lewis AM, Chan JW, Machin CL, Sinha D, Galione A, Churchill GC. 2010. The calcium-mobilizing messenger nicotinic acid adenine dinucleotide phosphate participates in sperm activation by mediating the acrosome reaction. J Biol Chem 285: 18262-18269. doi:10 .1074/jbc.M109.087858

Wada T, Nakashima T, Hiroshi N, Penninger JM. 2006. RANKL-RANK signalling in osteoclastogenesis and bone disease. Trends Mol Med 12: 17-25. doi:10.1016/j .molmed.2005.11.007

Wang X, Zhang X, Dong X, Samie M, Li X, Cheng X, Goschka A, Shen D, Zhou Y, Harlow J, et al. 2012. TPC 
TPCs in Development and Differentiation

proteins are phosphoinositide-activated sodium-selective ion channels in endosomes and lysosomes. Cell 151: 372383. doi:10.1016/j.cell.2012.08.036

Webb SE, Miller AL. 2011. Visualization of $\mathrm{Ca}^{2+}$ signaling during embryonic skeletal muscle formation in vertebrates. Cold Spring Harb Perspect Biol 3: a004325. doi:10.1101/cshperspect.a004325

West AE, Chen WG, Dalva MB, Dolmetsch RE, Kornhauser JM, Shaywitz AJ, Takasu MA, Tao X, Greenberg ME 2001. Calcium regulation of neuronal gene expression. Proc Natl Acad Sci 98: 11024-11031. doi:10.1073/pnas 191352298

Yavropoulou MP, Yovos JG. 2008. Osteoclastogenesis-Current knowledge and future perspectives. J Musculoskelet Neuronal Interact 8: 204-216.

Yoshida H, Hayashi SI, Kunisada T, Ogawa M, Nishikawa S, Okamura H, Sudo T, Shultz LD, Nishikawa SI. 1990. The murine mutation osteopetrosis is in the coding region of the macrophage colony stimulating factor gene. Nature 345: 442-444. doi:10.1038/345442a0

Zamora S, Rahman IA. 2014. Deciphering the early evolution of echinoderms with Cambrian fossils. Paleontol 57: 1105-1119. doi:10.1111/pala.12138

Zhang ZH, Lu YY, Yue J. 2013. Two pore channel 2 differentially modulates neural differentiation of mouse embryonic stem cells. PLoS ONE 8: e66077 doi:10.1371/jour nal.pone.0066077

Zhu MX, Ma J, Parrington J, Calcraft PJ, Galione A, Evans M. 2010. Calcium signaling via two-pore channels: Local or global, that is the question. Am J Physiol Cell Physiol 298: C430-C441. doi:10.1152/ajpcell.00475.2009

Zong X, Schieder M, Cuny H, Fenske S, Gruner C, Rötzer K, Griesbeck O, Harz H, Biel M, Wahl-Schott C. 2009. The two-pore channel TPCN2 mediates NAADP-dependent $\mathrm{Ca}^{2+}$-release from lysosomal stores. Pfligers Arch 458: 891-899. doi:10.1007/s00424-009-0690-y 


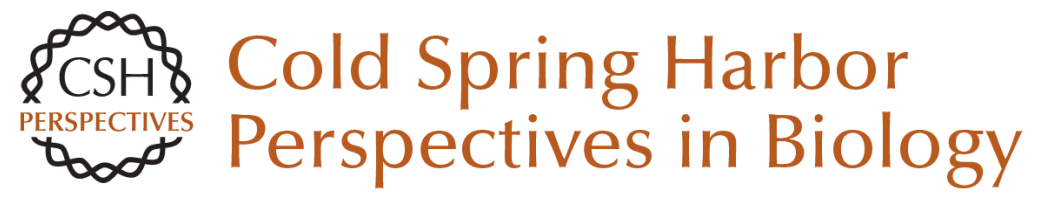

\section{Role of Two-Pore Channels in Embryonic Development and Cellular Differentiation}

Sarah E. Webb, Jeffrey J. Kelu and Andrew L. Miller

Cold Spring Harb Perspect Biol 2020; doi: 10.1101/cshperspect.a035170 originally published online July 29, 2019

\section{Subject Collection Calcium Signaling}

The Endoplasmic Reticulum-Plasma Membrane Junction: A Hub for Agonist Regulation of $\mathrm{Ca}^{2+}$ Entry

Hwei Ling Ong and Indu Suresh Ambudkar

Calcium-Handling Defects and Neurodegenerative

Disease

Sean Schrank, Nikki Barrington and Grace E. Stutzmann

Lysosomal $\mathrm{Ca}^{2+}$ Homeostasis and Signaling in Health and Disease

Emyr Lloyd-Evans and Helen Waller-Evans

$\mathrm{Ca}^{2+}$ Signaling in Exocrine Cells

Malini Ahuja, Woo Young Chung, Wei-Yin Lin, et al.

Functional Consequences of Calcium-Dependent Synapse-to-Nucleus Communication: Focus on Transcription-Dependent Metabolic Plasticity Anna M. Hagenston, Hilmar Bading and Carlos Bas-Orth

Identifying New Substrates and Functions for an Old Enzyme: Calcineurin

Jagoree Roy and Martha S. Cyert

Fundamentals of Cellular Calcium Signaling: A

Primer

Martin D. Bootman and Geert Bultynck
Primary Active $\mathrm{Ca}^{2+}$ Transport Systems in Health and Disease

Jialin Chen, Aljona Sitsel, Veronick Benoy, et al.

Signaling through $\mathrm{Ca}^{2+}$ Microdomains from

Store-Operated CRAC Channels

Pradeep Barak and Anant B. Parekh

Structural Insights into the Regulation of $\mathrm{Ca}^{2+}$

/Calmodulin-Dependent Protein Kinase II (CaMKII) Moitrayee Bhattacharyya, Deepti Karandur and John Kuriyan

Store-Operated Calcium Channels: From Function

to Structure and Back Again Richard S. Lewis

Bcl-2-Protein Family as Modulators of $\mathrm{IP}_{3}$

Receptors and Other Organellar $\mathrm{Ca} 2+$ Channels Hristina Ivanova, Tim Vervliet, Giovanni Monaco, et al.

Calcium Signaling in Cardiomyocyte Function Guillaume Gilbert, Kateryna Demydenko, Eef Dries, et al.

Cytosolic $\mathrm{Ca}^{2+}$ Buffers Are Inherently $\mathrm{Ca}^{2+}$ Signal Modulators Beat Schwaller

For additional articles in this collection, see http://cshperspectives.cshlp.org/cgi/collection/

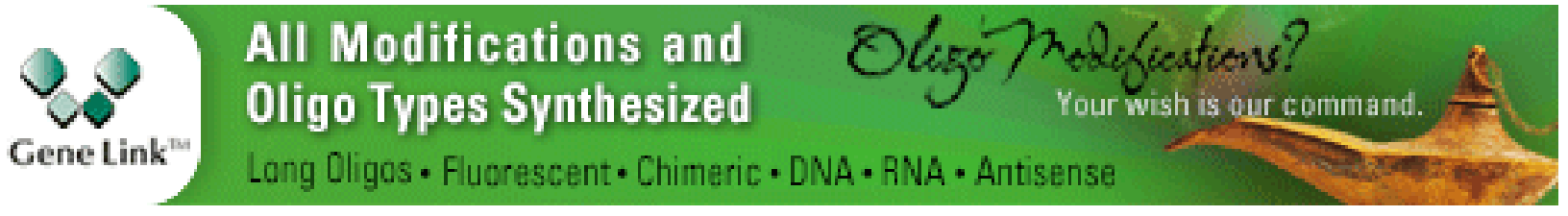


Role of Two-Pore Channels in Embryonic Development and Cellular Differentiation Sarah E. Webb, Jeffrey J. Kelu and Andrew L. Miller

\section{Organellar Calcium Handling in the Cellular \\ Reticular Network}

Wen-An Wang, Luis B. Agellon and Marek Michalak

For additional articles in this collection, see http://cshperspectives.cshlp.org/cgi/collection/

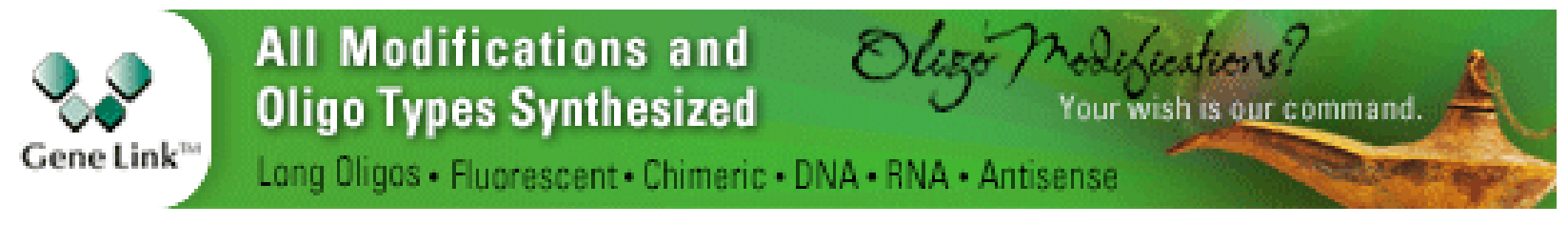

Copyright @ 2020 Cold Spring Harbor Laboratory Press; all rights reserved 